\title{
Article \\ Establishment of Regional Phytoremediation Buffer Systems for Ecological Restoration in the Great Lakes Basin, USA. I. Genotype $\times$ Environment Interactions
}

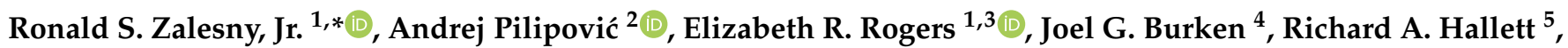 \\ Chung-Ho Lin ${ }^{3}$, Bernard G. McMahon ${ }^{6}$, Neil D. Nelson ${ }^{6}$, Adam H. Wiese ${ }^{1}$, Edmund O. Bauer ${ }^{1}$, Larry Buechel ${ }^{7}$, \\ Brent S. DeBauche ${ }^{3}$, Mike Peterson ${ }^{7}$, Ray Seegers ${ }^{8}$ and Ryan A. Vinhal ${ }^{1,3}$ \\ 1 USDA Forest Service, Northern Research Station, Institute for Applied Ecosystem Studies, \\ Rhinelander, WI 54501, USA; elizabeth.r.rogers@usda.gov (E.R.R.); adam.wiese@usda.gov (A.H.W.); \\ ebauer@charter.net (E.O.B.); ryan.vinhal@usda.gov (R.A.V.) \\ 2 Institute of Lowland Forestry and Environment, University of Novi Sad, 21000 Novi Sad, Serbia; \\ andrejp@uns.ac.rs \\ 3 Center for Agroforestry, School of Natural Resources, University of Missouri-Columbia, \\ Columbia, MO 65201, USA; LinChu@missouri.edu (C.-H.L.); debaucheb@umsystem.edu (B.S.D.) \\ 4 Department of Civil, Architectural and Environmental Engineering, Missouri University of Science and \\ Technology, Civil, Architectural, and Environmental Engineering, Rolla, MO 65401, USA; burken@mst.edu \\ check for \\ updates \\ Citation: Zalesny, R.S., Jr.; Pilipović, \\ A.; Rogers, E.R.; Burken, J.G.; Hallett, \\ R.A.; Lin, C.-H.; McMahon, B.G.; \\ Nelson, N.D.; Wiese, A.H.; Bauer, \\ E.O.; et al. Establishment of Regional \\ 5 USDA Forest Service, Northern Research Station, New York City Urban Field Station, \\ Bayside, NY 11360, USA; richard.hallett@usda.gov \\ 6 Natural Resources Research Institute, University of Minnesota Duluth, Duluth, MN 55807, USA; \\ bmcmahon@nrri.umn.edu (B.G.M.); nnelson2@d.umn.edu (N.D.N.) \\ 7 Environmental Legacy Management Group—Midwest, Waste Management, Inc., \\ Menomonee Falls, WI 53051, USA; lbuechel@wm.com (L.B.); mpeterso2@wm.com (M.P.) \\ 8 Waste Management of Wisconsin, Inc., Whitelaw, WI 54247, USA; rseegers@wm.com \\ * Correspondence: ronald.zalesny@usda.gov
} Phytoremediation Buffer Systems for Ecological Restoration in the Great Lakes Basin, USA. I. Genotype $\times$ Environment Interactions. Forests 2021, 12, 430. https://doi.org/ 10.3390/f12040430

Academic Editors: Francisca C. Aguiar

Received: 6 March 2021

Accepted: 30 March 2021

Published: 2 April 2021

Publisher's Note: MDPI stays neutral with regard to jurisdictional claims in published maps and institutional affiliations.

Copyright: () 2021 by the authors. Licensee MDPI, Basel, Switzerland. This article is an open access article distributed under the terms and conditions of the Creative Commons Attribution (CC BY) license (https:// creativecommons.org/licenses/by/ $4.0 /)$.
Abstract: Poplar remediation systems are ideal for reducing runoff, cleaning groundwater, and delivering ecosystem services to the North American Great Lakes and globally. We used phytorecurrent selection (PRS) to establish sixteen phytoremediation buffer systems (phyto buffers) (buffer groups: $2017 \times 6 ; 2018 \times 5 ; 2019 \times 5$ ) throughout the Lake Superior and Lake Michigan watersheds comprised of twelve PRS-selected clones each year. We tested for differences in genotypes, environments, and their interactions for health, height, diameter, and volume from ages one to four years. All trees had optimal health. Mean first-, second-, and third-year volume ranged from $71 \pm 26$ to $132 \pm 39 \mathrm{~cm}^{3} ; 1440 \pm 575$ to $5765 \pm 1132 \mathrm{~cm}^{3}$; and $8826 \pm 2646$ to $10,530 \pm 2110 \mathrm{~cm}^{3}$, respectively. Fourth-year mean annual increment of 2017 buffer group trees ranged from $1.1 \pm 0.7$ to $7.8 \pm 0.5 \mathrm{Mg} \mathrm{ha}^{-1} \mathrm{yr}^{-1}$. We identified generalist varieties with superior establishment across a broad range of buffers ('DM114', 'NC14106', '99038022', '99059016') and specialist clones uniquely adapted to local soil and climate conditions ('7300502', 'DN5', 'DN34', 'DN177', 'NM2', 'NM5', 'NM6'). Using generalists and specialists enhances the potential for phytoremediation best management practices that are geographically robust, being regionally designed yet globally relevant.

Keywords: ecosystem services; multi-environmental trials (MET); phenotypic plasticity; phyto buffers; phyto-recurrent selection; phytotechnologies; poplars; Populus

\section{Introduction}

Ninety-five percent of the United States' surface freshwater and $20 \%$ of the world's freshwater reserve are contained within the Great Lakes Basin [1,2]. The Basin provides ecosystem services (including clean drinking water) to over 34 million people in the United States and Canada [3-5], and contributes substantially to the United States' economy, with a gross regional product (GRP) estimated at nearly 4.1 trillion USD [6]. Anthropogenic 
activities in the region, combined with population growth and land use changes, induce a vast number of stressors such as toxic pollution, increases in invasive species populations, and climate change [7], all of which can disturb terrestrial water cycles [8] and impact water quality of the Great Lakes and their watersheds [9,10]. Non-point sources of pollution such as landfills and similar sites contribute to watershed contamination by runoff and leakage. Although pollutant levels within landfills generally decrease over time through chemical and biological alteration and degradation [11-13], treatment of leachate and wastewaters can help mitigate soil and water contamination [14]. Sustainable, long-term restoration practices are needed to preserve and enhance ecosystem services in the Great Lakes Basin. In the early 2010s, over 1.5 billion USD were invested in restoration projects to halt or mitigate pollution of the Great Lakes ecosystem [15]. Ecological restoration techniques and technologies are more economically viable and sustainable long-term solutions than off-site treatment methods for mitigating contamination.

Ecological restoration may help reverse land degradation, improve the resilience of biodiversity, and deliver important ecosystem services [16,17]. Phytotechnologies are an ideal solution for preventing water contamination, and they include biological recovery activities that have been classified into four categories: remediation, reclamation, restoration, and rehabilitation [18]. The most common phytotechnology, phytoremediation, involves the use of plants for remediation and prevention of water contamination [19]. Often, phytoremediation is accomplished by installing vegetative covers, riparian buffers, and/or hydraulic control systems. Depending upon their type and chemical properties, contaminants are accumulated, immobilized, metabolized or volatilized [20-22].

Fast-growing trees such as Populus L. species and their hybrids (hereafter referred to as poplars) have been studied and used in plantation-based silvicultural systems known as short rotation woody crop (SRWC) systems for over 100 years $[23,24]$. The primary focus for SRWCs has been on the production of wood and wood products. More recently, poplar production systems have been implemented to provide a variety of ecosystem services [25-27], including their application in phytotechnologies for ecological clean up and restoration [28]. Phytoremediation research starting in the 1990s showed that poplars were great candidates for remediation systems because of their vigorous growth, easy vegetative propagation, well-developed root systems, and high productivity on marginal and liability lands $[27,29,30]$. The results of such studies indicate the potential of poplars for phytoremediation of various inorganic and organic contaminants [20,31-35]. Another factor that adds to the value of poplars in phytoremediation is that they exhibit a broad range of genetic diversity given their ability to undergo spontaneous and controlled intra- and inter-species hybridization, which thereby creates a high number of simple and complex hybrids [36].

Phytoremediation projects are often installed on sites and in soils that are not ideal for plant growth. Variability in environmental conditions affects evolutionary processes of populations or individuals within species, resulting in broadening or narrowing of their ecological niches, defined as generalists and specialists, respectively [37,38]. Poplars are ideal candidates for tree improvement by hybridization and breeding [39-41], with further aims to fully exploit poplar genomic and genetic potential and maximize wood biomass productivity from fast-growing trees worldwide. The ability of genotypes to produce different phenotypes in distinct environmental conditions is defined as phenotypic plasticity, and includes variation in the morphology, physiology, behavior, and life history of organisms [42]. This can lead to unpredictability in performance that can complicate selection of proper genotypes for phytoremediation projects. The genotype by environment $(G \times E)$ interaction, in which a phenotype is a function of the genotype, the environment, and the differential phenotypic response of genotypes to site-specific edaphic and climatic conditions, is a determining factor of clonal site performance [43]. Such interaction exists when comparative performances of genotypes vary according to local site conditions, with superiority of a genotype in a certain environment converted to inferiority in another environment [44]. Genotypic variability across a variety of environments can lead to unpre- 
dictability in performance that can complicate selection of proper genotypes for commercial use. Therefore, in tree breeding, multi-environmental trials (MET) are implemented to evaluate the degree and pattern of $\mathrm{G} \times \mathrm{E}$ interactions, as well as to test the robustness of genotypes in different environments $[45,46]$.

However, sometimes phenotypic plasticity can hinder expression of $G \times E$ interactions. For example, testing of hybrid poplar clones for growth performance and robustness at different sites in the Midwestern USA showed low $\mathrm{G} \times \mathrm{E}$ interaction and high plasticity of tested genotypes, indicating their suitability for growing on a wider spectrum of habitats [46,47]. In poplar research, $G \times E$ interactions and definitions of generalists vs specialists have been studied for various traits ranging from biomass production [48-50] and rooting ability [51], to physiological traits related to productivity [36] and drought tolerance [52], to wood properties [53,54]. Often, $\mathrm{G} \times \mathrm{E}$ interactions are also determined by the genomic groups of the hybrids, where components of different Populus species (e.g., P. deltoides Bartr. ex. Marsh, P. maximowiczii A. Henry, P. nigra L., P. trichocarpa Torr. et Gray) significantly contribute to the expression of specific traits by a given genotype, and are reflected in rooting ability and adaptability to certain climate, latitude or soil-water conditions $[48,49,55,56]$. Therefore, clonal testing to maximize understanding of $\mathrm{G} \times \mathrm{E}$ interactions is paramount in establishing successful poplar plantings for a broad range of end uses and ecosystem services, including environmental objectives such as phytoremediation. For example, optimizing $\mathrm{G} \times \mathrm{E}$ interactions may be most appropriate for small-scale applications with site-specific needs, while minimum $\mathrm{G} \times \mathrm{E}$ interactions are needed to deploy superior and robust clones at a justifiable cost for large-scale commercial systems [46].

The current study is a component of a regional phytoremediation testing network originally funded by the Great Lakes Restoration Initiative (GLRI) [2] to select and test the ability of new poplar genotypes to reduce surface runoff and prevent groundwater contamination at landfills and similar sites in the Great Lakes Basin. We implemented phyto-recurrent selection, a stepwise greenhouse- and field-based approach that combines crop and tree improvement strategies to evaluate, identify and select superior-performing clones based on multiple testing cycles [32,57]. Results of the initial screening of candidate clones in greenhouse experiments, previously published by Rogers et al. [58], were used to develop the MET testing network consisting of sixteen phytoremediation buffer systems (i.e., phyto buffers) at ten sites located in the Lake Superior (i.e., Michigan's Upper Peninsula) and Lake Michigan (i.e., eastern Wisconsin) watersheds. Our objective was to test for differences in genotypes, environments, and their interactions for health, height, diameter, and volume during early field establishment (i.e., from one to four years after planting). Our results identify poplar clones with maximum phytoremediation potential that can be established across a wide range of environmental conditions. These data are useful for clonal selection to maximize phytoremediation potential in future phytotechnologies, regardless of specific site conditions or genotypes deployed.

\section{Materials and Methods}

\subsection{Site Description}

A regional phytotechnologies network consisting of sixteen phytoremediation buffer systems (i.e., phyto buffers) was established in 2017 ( $\times 6$ phyto buffers), $2018(\times 5)$, and $2019(\times 5)$ in the Lake Superior watershed of the Upper Peninsula of Michigan, USA and the Lake Michigan watershed of eastern Wisconsin, USA. Multiple phyto buffers were installed at some locations, resulting in ten field testing sites throughout the network (Figure 1). The sites ranged in latitude from 46.7840 to $42.8382{ }^{\circ} \mathrm{N}$ and in longitude from -89.1291 to $-86.5976^{\circ} \mathrm{W}$, which is consistent with poplar productivity supplysheds in the region [47,59-61]. Site-related climate properties are shown in Table 1. Twentyyear historical monthly averages for precipitation, temperature, and drought were determined across each growing season (April to October) for the time period 2000 to 2020 and summed (precipitation) and averaged (temperature, drought) to obtain final annual 
values. Based on the nearest weather station to each site, precipitation $(\mathrm{P}, \mathrm{mm})$ along with maximum $\left(\mathrm{T}_{\max },{ }^{\circ} \mathrm{C}\right)$ and minimum $\left(\mathrm{T}_{\min },{ }^{\circ} \mathrm{C}\right)$ air temperatures were obtained from the National Oceanic and Atmospheric Administration (NOAA) National Climate Data Center (https:/ / www.ncdc.noaa.gov/cdo-web/, accessed on 20 January 2021). Average temperature (i.e., $\left.\mathrm{T}_{\mathrm{avg}}=\left(\left(\mathrm{T}_{\max }+\mathrm{T}_{\min }\right) / 2\right),{ }^{\circ} \mathrm{C}\right)$ and the difference between maximum and minimum temperatures (i.e., $\mathrm{T}_{\text {diff }}=\mathrm{T}_{\max }-\mathrm{T}_{\min },{ }^{\circ} \mathrm{C}$ ) were calculated for each site. Daily growing degree days $\left(\mathrm{GDD}_{\text {day }}\right)$ were calculated as the average temperature minus a base temperature of $10{ }^{\circ} \mathrm{C}$ (i.e., $\mathrm{GDD}_{\text {day }}=\mathrm{T}_{\text {avg }}-10{ }^{\circ} \mathrm{C}$ ) and summed across each growing season. Average annual growing degree days for each site $\left(\mathrm{GDD}_{\text {annual }}\right)$ were estimated by averaging the seasonal GDD values from 2000 to 2020. The United States Drought Monitor (https: / / droughtmonitor.unl.edu/, accessed on 20 January 2021) was accessed to obtain drought index scores according to percent area within each county belonging to four drought index categories: D0 (abnormally dry), D1 (moderate drought), D2 (severe drought), D3 (extreme drought), and D4 (exceptional drought). Categories D3 and D4 were negligible and, therefore, not reported in Table 1. Buffer-specific soil properties were acquired from the USDA Natural Resources Conservation Service (NRCS) Web Soil Survey (https:/ / websoilsurvey.sc.egov.usda.gov/, accessed on 20 January 2021) and are provided in Table 2.

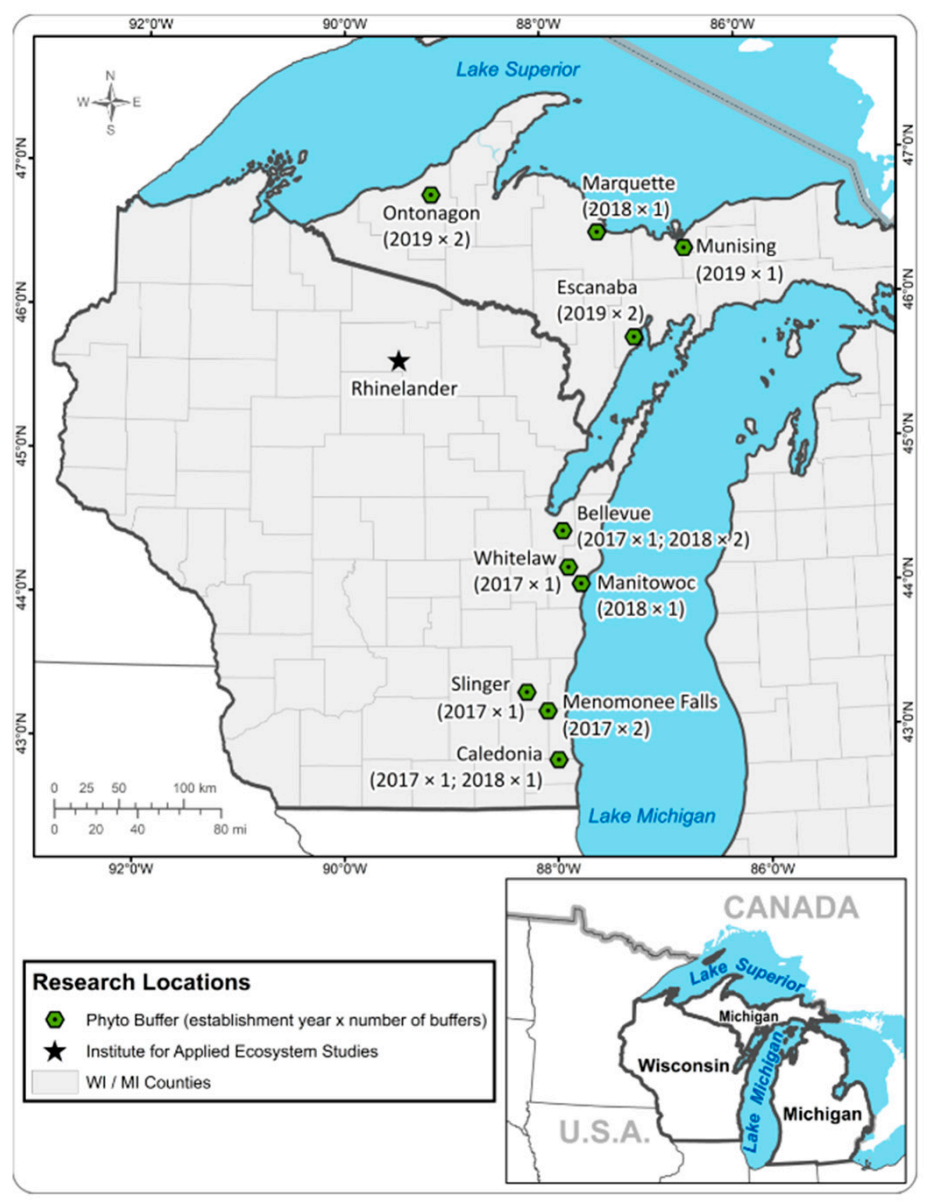

Figure 1. Regional phytotechnologies network consisting of sixteen phytoremediation buffer systems (i.e., phyto buffers) established in 2017 ( $\times 6$ phyto buffers), $2018(\times 5)$, and $2019(\times 5)$ in the Lake Superior watershed of the Upper Peninsula of Michigan, USA and the Lake Michigan watershed of eastern Wisconsin, USA. 
Table 1. Precipitation, temperature, growing degree days, and drought indices of ten field testing sites in a regional phyto technologies network consisting of sixteen phytoremediation buffer systems (i.e., phyto buffers) established from 2017 to 2019 in the Lake Superior watershed of the Upper Peninsula of Michigan, USA and the Lake Michigan watershed of eastern Wisconsin, USA.

\begin{tabular}{|c|c|c|c|c|c|}
\hline Site & Bellevue, WI & Caledonia, WI & Escanaba, MI & Manitowoc, WI & Marquette, MI \\
\hline County & Brown & Racine & Delta & Manitowoc & Marquette \\
\hline Buffer group (i.e., year of planting) & 2017,2018 & 2017,2018 & 2019 & 2018 & 2018 \\
\hline Total number of phyto buffers & 3 & 2 & 2 & 1 & 1 \\
\hline Annual precipitation $(\mathrm{P})(\mathrm{mm})$ & $613 \pm 27$ & $686 \pm 36$ & $556 \pm 32$ & $614 \pm 27$ & $530 \pm 28$ \\
\hline Average temperature $\left(\mathrm{T}_{\mathrm{avg}}\right)\left({ }^{\circ} \mathrm{C}\right)$ & $15.3 \pm 0.2$ & $15.7 \pm 0.2$ & $13.6 \pm 0.2$ & $14.8 \pm 0.2$ & $13.1 \pm 0.4$ \\
\hline Maximum temperature $\left(\mathrm{T}_{\max }\right)\left({ }^{\circ} \mathrm{C}\right)$ & $21.1 \pm 0.2$ & $21.5 \pm 0.2$ & $20.0 \pm 0.3$ & $19.2 \pm 0.3$ & $17.3 \pm 0.4$ \\
\hline Minimum temperature $\left(\mathrm{T}_{\min }\right)\left({ }^{\circ} \mathrm{C}\right)$ & $9.5 \pm 0.1$ & $10.0 \pm 0.1$ & $7.2 \pm 0.2$ & $10.4 \pm 0.2$ & $8.9 \pm 0.4$ \\
\hline $\begin{array}{l}\text { Maximum-minimum temperature } \\
\qquad\left(\mathrm{T}_{\text {diff }}\right)\left({ }^{\circ} \mathrm{C}\right)\end{array}$ & $11.6 \pm 0.1$ & $11.5 \pm 0.1$ & $12.8 \pm 0.2$ & $15.8 \pm 0.4$ & $8.5 \pm 0.1$ \\
\hline $\begin{array}{l}\text { Annual growing degree days } \\
\left(\mathrm{GDD}_{\text {annual }}\right)\end{array}$ & $1342 \pm 27$ & $1418 \pm 31$ & $1017 \pm 24$ & $1213 \pm 37$ & $997 \pm 54$ \\
\hline $\begin{array}{l}\text { Drought index (abnormally dry) } \\
\text { (D0) }(\%)\end{array}$ & $24.0 \pm 5.3$ & $22.4 \pm 5.7$ & $31.4 \pm 6.9$ & $20.1 \pm 5.0$ & $36.5 \pm 7.7$ \\
\hline $\begin{array}{l}\text { Drought index (moderate drought) } \\
\text { (D1) }(\%)\end{array}$ & $8.0 \pm 3.1$ & $9.5 \pm 4.6$ & $10.3 \pm 3.8$ & $7.9 \pm 3.2$ & $14.7 \pm 4.8$ \\
\hline $\begin{array}{l}\text { Drought index (severe drought) } \\
\text { (D2) }(\%)\end{array}$ & $0.8 \pm 0.8$ & $4.9 \pm 3.0$ & $3.9 \pm 2.0$ & $1.2 \pm 1.1$ & $4.5 \pm 2.4$ \\
\hline Site & $\begin{array}{l}\text { Menomonee } \\
\text { Falls, WI }\end{array}$ & Munising, MI & Ontonagon, MI & Slinger, WI & Whitelaw, WI \\
\hline County & Waukesha & Alger & Ontonagon & Washington & Manitowoc \\
\hline Buffer group (i.e., year of planting) & 2017 & 2019 & 2019 & 2017 & 2017 \\
\hline Total number of phyto buffers & 2 & 1 & 2 & 1 & 1 \\
\hline Annual precipitation $(\mathrm{P})(\mathrm{mm})$ & $649 \pm 23$ & $655 \pm 25$ & $551 \pm 26$ & $653 \pm 36$ & $640 \pm 26$ \\
\hline Average temperature $\left(\mathrm{T}_{\mathrm{avg}}\right)\left({ }^{\circ} \mathrm{C}\right)$ & $15.3 \pm 0.1$ & $12.3 \pm 0.2$ & $13.4 \pm 0.2$ & $15.1 \pm 0.2$ & $14.9 \pm 0.1$ \\
\hline Maximum temperature $\left(\mathrm{T}_{\max }\right)\left({ }^{\circ} \mathrm{C}\right)$ & $21.2 \pm 0.2$ & $17.0 \pm 0.2$ & $19.7 \pm 0.3$ & $21.1 \pm 0.2$ & $21.0 \pm 0.2$ \\
\hline Minimum temperature $\left(\mathrm{T}_{\min }\right)\left({ }^{\circ} \mathrm{C}\right)$ & $9.4 \pm 0.1$ & $7.7 \pm 0.2$ & $7.1 \pm 0.2$ & $9.0 \pm 0.2$ & $8.9 \pm 0.1$ \\
\hline $\begin{array}{c}\text { Maximum-minimum temperature } \\
\left(\mathrm{T}_{\text {diff }}\right)\left({ }^{\circ} \mathrm{C}\right)\end{array}$ & $11.8 \pm 0.1$ & $9.3 \pm 0.1$ & $12.7 \pm 0.1$ & $12.1 \pm 0.1$ & $12.1 \pm 0.1$ \\
\hline $\begin{array}{l}\text { Annual growing degree days } \\
\left(\mathrm{GDD}_{\text {annual }}\right)\end{array}$ & $1344 \pm 26$ & $877 \pm 30$ & $1044 \pm 39$ & $1286 \pm 29$ & $1295 \pm 26$ \\
\hline $\begin{array}{l}\text { Drought index (abnormally dry) } \\
\text { (D0) (\%) }\end{array}$ & $20.9 \pm 5.4$ & $28.4 \pm 6.4$ & $37.9 \pm 8.0$ & $17.7 \pm 5.1$ & $20.1 \pm 5.0$ \\
\hline $\begin{array}{l}\text { Drought index (moderate drought) } \\
\text { (D1) }(\%)\end{array}$ & $9.1 \pm 4.4$ & $9.0 \pm 3.3$ & $15.2 \pm 6.3$ & $9.2 \pm 4.2$ & $7.9 \pm 3.2$ \\
\hline $\begin{array}{c}\text { Drought index (severe drought) } \\
\text { (D2) }(\%)\end{array}$ & $4.1 \pm 2.5$ & $3.6 \pm 2.1$ & $7.2 \pm 3.8$ & $2.7 \pm 1.7$ & $1.2 \pm 1.1$ \\
\hline
\end{tabular}

Climate and drought data are means \pm one standard error across each growing season (April to October) from 2000 to 2020. Climate source: National Oceanic and Atmospheric Administration (NOAA) National Climate Data Center (https://www.ncdc.noaa.gov/cdo-web/, accessed on 20 January 2021). Drought source: United States Drought Monitor (https://droughtmonitor.unl.edu/, accessed on 20 January 2021); percent of area within the county in each category (D0 to D2).

\subsection{Clone Selection}

Phyto-recurrent selection was conducted through a polycyclic evaluation process to choose superior genotypes for out planting [32,58,62]. For each phyto buffer, soils were collected in the field, brought to the USDA Forest Service, Institute for Applied Ecosystem Studies in Rhinelander, Wisconsin, USA (Figure 1), and processed (i.e., dried and sifted to remove large debris) for use as soil treatments during three greenhouse selection cycles [58]. The number of clones tested in each cycle decreased from 140 (cycle 1) to 60 (cycle 2) to 15 (cycle 3) based on multiplicative rank summation indices incorporating tree survival, growth, physiology, and health [63]. Twelve clones were selected for cycle 4 field testing, resulting in three buffer groups related to phyto buffer establishment in 2017, 2018, and 2019. Phyto buffers within buffer group years had the same twelve clones, but the twelve clones differed among the three buffer groups based on cycle 3 phyto-recurrent selection 
results. In the current study, separate analyses were conducted for each buffer group. Each set of buffer group clones consisted of genotypes that have: (1) been commonly used for commercial and/or research purposes in the region (i.e., Common clones), (2) a rich history of testing but are still at the experimental stage (i.e., Experimental), and (3) been bred, tested, and selected at the University of Minnesota Duluth, Natural Resources Research Institute (NRRI) and show promise for broad-ranging applications (i.e., NRRI) [46,56]. Specific clones and their genomic groups are listed in Table 3.

Table 2. Soil properties of sixteen phytoremediation buffer systems (i.e., phyto buffers) comprising a regional phytotechnologies network established from 2017 to 2019 in the Lake Superior watershed of the Upper Peninsula of Michigan, USA and the Lake Michigan watershed of eastern Wisconsin, USA.

\begin{tabular}{|c|c|c|c|c|c|c|c|c|c|c|c|c|c|}
\hline Phyto Buffer ${ }^{a}$ & BC & $\mathrm{BE}$ & BW & $\mathrm{CE}$ & $\mathrm{CW}$ & $\mathrm{EE}, \mathrm{EW}$ & MA & ME, MW & MQ & MU & ON, OS & SL & WH \\
\hline Soil series & Manawa & Kewaunee & Bellevue & Fox & Matherton & Croswell & Hochheim & Sebewa & Schweitzer & Kalkaska & Oldman & Casco & Boyer \\
\hline Drainage class $b$ & SPD & WD & SPD & MWD & SPD & MWD & WD & PD & WD & SED & MWD & SED & WD \\
\hline Slope (\%) & 0 to 3 & 2 to 6 & 2 to 6 & 2 to 6 & 1 to 3 & 0 to 3 & 6 to 12 & 0 to 2 & 6 to 25 & 0 to 6 & 6 to 35 & 20 to 30 & 6 to 12 \\
\hline $\begin{array}{l}\mathrm{K} \text { factor (erodibility, } 0.02 \text { to } 0.69 \\
\text { scale) }\end{array}$ & 0.37 & 0.49 & 0.28 & 0.37 & 0.28 & 0.05 & 0.37 & 0.37 & 0.20 & 0.04 & 0.37 & 0.32 & 0.43 \\
\hline Texture $^{c}$ & $\mathrm{SiCL}$ & $\mathrm{SiCL}$ & $\mathrm{SiCL}$ & $\mathrm{L}$ & $\mathrm{L}$ & $\mathrm{s}$ & $\mathrm{L}$ & $\mathrm{L}$ & SL & $\mathrm{s}$ & $\mathrm{L}$ & SL & SCL \\
\hline Sand $(\%)$ & 10.1 & 13.3 & 19.8 & 39.5 & 50.1 & 87.4 & 45.4 & 37.3 & 55.9 & 94.7 & 51.4 & 54.0 & 58.2 \\
\hline Silt $(\%)$ & 45.9 & 47.7 & 50.0 & 39.7 & 28.1 & 10.4 & 34.4 & 42.1 & 41.1 & 4.4 & 41.4 & 28.6 & 18.8 \\
\hline Clay $(\%)$ & 44.0 & 39.0 & 30.2 & 20.8 & 21.8 & 2.2 & 20.2 & 20.6 & 3.0 & 0.9 & 7.2 & 17.4 & 23.0 \\
\hline Organic matter (\%) & 1.3 & 1.1 & 3.7 & 1.1 & 1.5 & 6.8 & 1.3 & 1.5 & 2.2 & 3.5 & 6.4 & 0.6 & 0.4 \\
\hline Soil organic carbon (\%) & 0.7 & 0.6 & 2.2 & 0.6 & 0.9 & 4.0 & 0.7 & 0.8 & 1.3 & 2.0 & 3.7 & 0.4 & 0.2 \\
\hline $\mathrm{pH}$ & 7.0 & 6.6 & 7.2 & 5.8 & 6.2 & 4.9 & 7.4 & 7.0 & 4.9 & 5.0 & 4.6 & 7.4 & 6.9 \\
\hline Bulk density $\left(\mathrm{g} \mathrm{cm}^{-3}\right)$ & 1.43 & 1.45 & 1.48 & 1.53 & 1.52 & 1.45 & 1.51 & 1.47 & 1.47 & 1.51 & 1.36 & 1.53 & 1.61 \\
\hline $\begin{array}{c}\text { Cation exchange capacity } \\
\left.\text { (meq } 100 \mathrm{~g}^{-1}\right)\end{array}$ & 23.1 & 20.0 & 25.0 & 12.7 & 13.6 & $\mathrm{na}^{\mathrm{d}}$ & 10.8 & 17.1 & 7.4 & 1.1 & na & 13.8 & 8.1 \\
\hline $\begin{array}{c}\text { Saturated hydraulic } \\
\text { conductivity (Ksat) }\left(\mu \mathrm{m} \mathrm{sec}^{-1}\right)\end{array}$ & 1.6 & 3.4 & 3.0 & 9.0 & 17.7 & 91.7 & 6.5 & 9.0 & 8.0 & 90.3 & 20.0 & 13.2 & 13.2 \\
\hline Frost free days (\#) & 160 & 160 & 135 & 173 & 150 & 130 & 145 & 152 & 115 & 130 & 110 & 169 & 140 \\
\hline Depth to water table $(\mathrm{cm})$ & $>200$ & $>200$ & 0 & 178 & 30 & 60 & $>200$ & 15 & $>200$ & $>200$ & 30 & $>200$ & $>200$ \\
\hline $\begin{array}{l}\text { Available water capacity } \\
\qquad\left(\mathrm{cm} \mathrm{cm}^{-1}\right)\end{array}$ & 0.1 & 0.2 & 0.2 & 0.2 & 0.2 & 0.1 & 0.2 & 0.2 & 0.1 & 0.1 & 0.1 & 0.1 & 0.2 \\
\hline Available water storage $(\mathrm{cm})$ & 8.4 & 8.8 & 11.6 & 10.9 & 10.0 & 6.0 & 9.1 & 12.0 & 7.7 & 5.0 & 8.3 & 6.0 & 8.7 \\
\hline Water content (15 Bar) $(\%)$ & 25.7 & 22.1 & 22.7 & 13.5 & 14.2 & 3.1 & 12.7 & 13.1 & 3.5 & 2.7 & 3.2 & 11.2 & 14.3 \\
\hline Water content $(1 / 3$ Bar $\%)$ & 33.9 & 31.4 & 34.3 & 26.8 & 24.2 & 11.7 & 23.4 & 26.3 & 10.7 & 9.2 & 9.3 & 21.0 & 21.5 \\
\hline
\end{tabular}

Source: USDA Natural Resources Conservation Service (NRCS) Web Soil Survey (https: / websoilsurvey.sc.egov.usda.gov/, accessed on 20 January 2021). ${ }^{\text {a }}$ Phyto buffers: BC: Bellevue (Central); BE: Bellevue (East); BW: Bellevue (West); CE: Caledonia (East); CW: Caledonia (West); EE: Escanaba (East); EW: Escanaba (West); MA: Manitowoc; ME: Menomonee Falls (East); MW: Menomonee Falls (West); MQ: Marquette; MU: Munising; ON: Ontonagon (North); OS: Ontonagon (South); SL: Slinger; WH: Whitelaw. ${ }^{\text {b }}$ Drainage classes: MWD: moderately well drained; PD: poorly drained; SED: somewhat excessively drained; SPD: somewhat poorly drained; WD: well drained. ${ }^{\mathrm{c}}$ Textures: L: loam; S: sand; SCL: sandy clay loam; SiCL: silty clay loam; SL: sandy loam. ${ }^{\mathrm{d}}$ na: not available.

Table 3. Genomic groups, clones, buffer groups (i.e., years of planting), and clone groups for Populus genotypes tested in a regional phyto technologies network of sixteen phytoremediation buffer systems (i.e., phyto buffers) established from 2017 to 2019 in the Lake Superior watershed of the Upper Peninsula of Michigan, USA and the Lake Michigan watershed of eastern Wisconsin, USA.

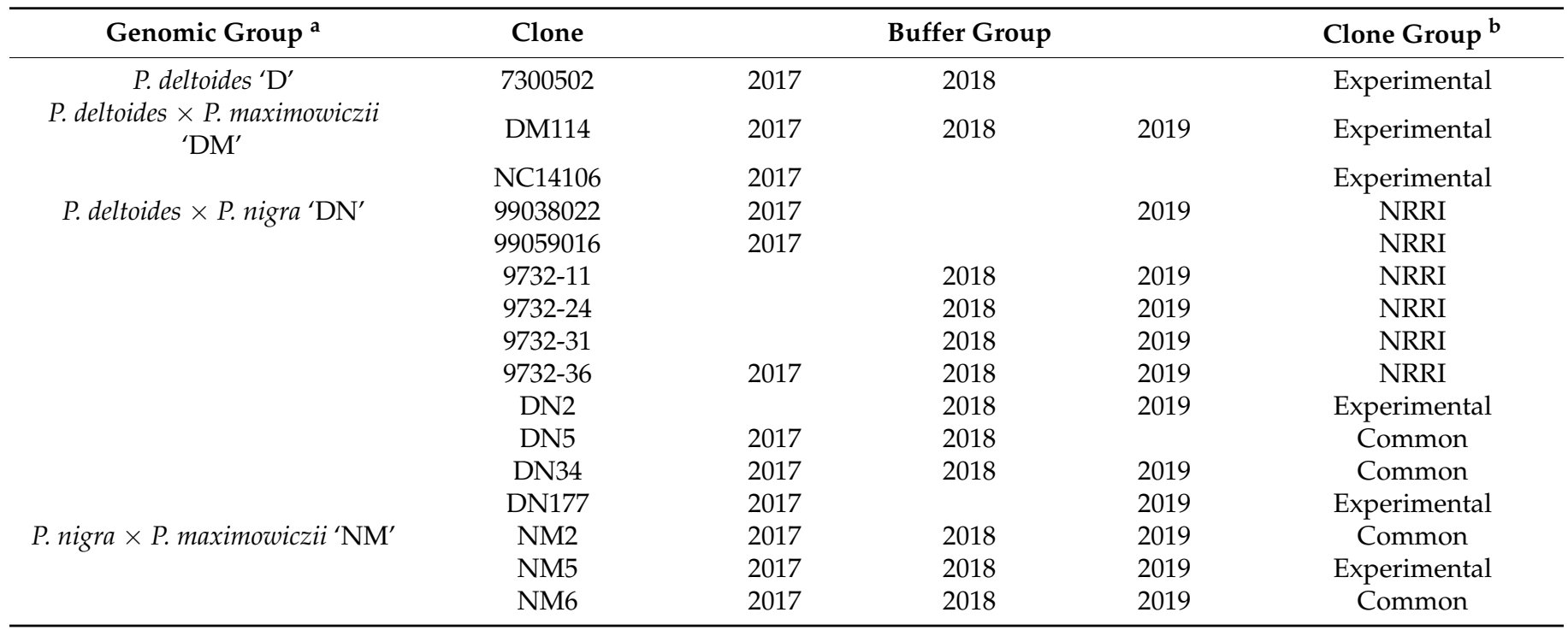

a Species authorities: P. deltoides Bartr. Ex Marsh; P. nigra L.; P. maximowiczii A. Henry NRRI = promising genotypes bred, tested, and selected at the University of Minnesota Duluth, Natural Resources Research Institute (NRRI) for broad-ranging applications [46,56]; ${ }^{\mathrm{b}}$ Experimental $=$ genotypes with a rich history of testing but that are still at the experimental stage; Common = genotypes commonly used for commercial and/or research purposes in the region. 


\subsection{Phyto Buffer Establishment and Experimental Design}

Dormant, unrooted hardwood cuttings (measuring $25.4 \mathrm{~cm}$ in length, and containing at least one primary bud within $2.54 \mathrm{~cm}$ from the top of each cutting) were processed from one-year-old whips collected during the dormant season (i.e., January through March) from: the USDA Forest Service Hugo Sauer Nursery (Rhinelander, WI, USA); University of Minnesota NRRI Clonal Orchard at the North Central Research and Outreach Center Nursery (Grand Rapids, Minnesota, USA); Iowa State University Clonal Orchard at the Iowa Department of Natural Resources State Nursery (Ames, IA, USA); and Michigan State University Clonal Orchard at the Tree Research Center (Lansing, MI, USA).

Processed cuttings were stored in polyethylene bags at $5^{\circ} \mathrm{C}$ and, prior to planting, soaked in water to a height of $16.93 \mathrm{~cm}$ for $48 \mathrm{~h}$ in a dark room at $21^{\circ} \mathrm{C}$ during May and June in 2017, 2018, and 2019 (Table S1). Prior to planting, rocks and other large obstructions were removed and the soil was tilled to a depth of $30 \mathrm{~cm}$. Thus, at planting, there was no competition from weeds and/or grasses. To reduce potential competition effects over time, subsequent site maintenance throughout the study period included: (1) tilling to a depth of $30 \mathrm{~cm}$, (2) hand weeding to a minimum diameter of $0.61 \mathrm{~m}$ around each individual tree, and (3) removing rocks and other obstructions. For each phyto buffer, a minimum of one maintenance cycle per month throughout each growing season was conducted.

At each of the six $(2017)$ or five $(2018,2019)$ phyto buffers, trees were planted in a randomized complete block design (RCBD) with eight blocks and twelve clones at a spacing of $2.44 \mathrm{~m} \times 2.44 \mathrm{~m}$ (i.e., 1680 trees ha $^{-1}$ ). Due to field space constraints, four blocks were planted at Slinger, Wisconsin. Clones were arranged in randomized complete blocks to minimize effects of potential environmental gradients, especially those related to runoff and soil physico-chemical properties. Two border rows were established on the perimeter of each phyto buffer to reduce potential border effects [64,65]. All phyto buffers were fenced using $2.3 \mathrm{~m}$ tall Trident extra strength deer fencing (Trident Enterprises, Waynesboro, PA, USA) to eliminate potential impacts from white-tailed deer (Odocoileus virginianus Zimmerman) browse. At the end of the first growing season, tree survival across all phyto buffers and clones was $97.1 \%$, with $95.5 \%, 96.2 \%$, and $99.6 \%$ survival for the 2017, 2018, and 2019 buffer groups, respectively. All trees that died were replanted with the same genotype to ensure full stocking of 1680 trees ha ${ }^{-1}$. However, the replanted trees were not included in the analyses below.

\subsection{Field Measurements}

At the end of each growing season, tree height to the nearest $0.1 \mathrm{~m}$ was measured from the ground to the apical bud. Diameter was measured at $10 \mathrm{~cm}$ above the soil surface for one- and two-year-old trees and at breast height (i.e., DBH at $1.37 \mathrm{~m}$ ) for three-year-old trees. All diameter estimates were determined to the nearest $0.1 \mathrm{~cm}$. Tree volume $(\mathrm{V})$ was calculated from height $(\mathrm{H})$ and diameter $(\mathrm{D}$; including one- and two-year diameter and DBH) using the model: $\mathrm{V}=\mathrm{D}^{2} \times \mathrm{H}$ [66]. Starting in 2020, trees of the 2017 buffer group were too tall to continue height measurements at the requisite precision noted above. As a result, 2020 DBH measurements collected from 2017 buffer group trees were used to estimate mean annual increment (MAI; $\mathrm{Mg} \mathrm{ha}^{-1} \mathrm{yr}^{-1}$ ). In this particular case, individualtree biomass was estimated using the general model: Biomass $=10^{\mathrm{a} 0} \times \mathrm{DBH}^{\mathrm{a} 1}$ while applying genomic-group specific coefficients from Headlee and Zalesny [67] (P. deltoides ' $\mathrm{D}^{\prime}: \mathrm{a}_{0}=-0.65, \mathrm{a}_{1}=2.01 ;$ P. deltoides $\times$ P. nigra ' $\mathrm{DN}^{\prime}: \mathrm{a}_{0}=-1.02, \mathrm{a}_{1}=2.36 ;$ P. deltoides $\times$ P. maximowiczii ' $\mathrm{DM}^{\prime}$ ': $\mathrm{a}_{0}=-1.03, \mathrm{a}_{1}=2.33 ; P$. nigra $\times P$. maximowiczii ' $\mathrm{NM}^{\prime}$ ': $\mathrm{a}_{0}=-0.50$, $\left.\mathrm{a}_{1}=1.94\right)$. Individual-tree biomass estimates were then scaled to MAI using standard metric conversion factors and stocking of 1680 trees ha $^{-1}$ at four years after planting.

\subsection{Health Assessments}

Based on a modified methodology of Rogers et al. [58], individual tree health parameters were scored using a five-category qualitative scale ranging from 1 to 5 , where $1=$ optimal health, $2=$ good health, $3=$ moderate health, $4=$ poor health, and $5=$ dead (i.e., 
health score was inversely related to health). Two researchers scored each parameter to promote consistency in ratings. There were six parameters: (1) vigor, (2) defoliation, (3) leaf discoloration, (4) chlorosis, (5) leaf scorch, and (6) leaf spots. A multiplicative weighted summation index was used to calculate final health index values, with vigor receiving a coefficient of 0.25 and all other parameters having a health coefficient equal to 0.15 . Health assessments were not conducted in 2020.

\subsection{Data Analysis}

Health (of all buffer groups) and MAI (of the 2017 buffer group) data were subjected to analyses of variance (ANOVA) and analyses of means (ANOM) using SAS ${ }^{\circledR}$ (PROC GLM; PROC ANOM; SAS INSTITUTE, INC., Cary, NC, USA) assuming a two-way factorial design including six $(2017)$ or five $(2018,2019)$ buffers, twelve clones, and their interactions. Fisher's Least Significant Difference (LSD) was used to identify significant differences among least-squares means for main effects and interactions at $P<0.05$.

Height and volume (of all buffer groups) and diameter (excluding 2020 diameter of 2017 buffer group trees) data were subjected to analyses of variance (ANOVA) and analyses of means (ANOM) using SAS ${ }^{\circledR}$ (PROC MIXED; PROC ANOM; SAS INSTITUTE, INC., Cary, NC, USA) assuming a three-way, repeated measures factorial design including six (2017) or five $(2018,2019)$ buffers, twelve clones, three $(2017,2018)$ or two $(2019)$ ages, and their interactions. The ages (representing tree growth after each growing season) were analyzed as the repeated measure. To account for pseudo-replication over time, six different covariance structures (i.e., vc, cs, ar (1), toep, ante (1), un) were tested in PROC MIXED to determine which one provided the best model fit based on the lowest BIC scores. Using these covariance structures, ANOVA were conducted in PROC MIXED for all traits, and multiple comparisons analyses were conducted to identify significant differences among least-squares means for main effects and interactions as noted above.

\section{Results}

\subsection{Health}

There were significant differences in health of the 2017 buffer group trees $\left(\mathrm{HEALTH}_{2017}\right)$ among buffer and clone main effects for the first, second, and third year of growth $\left(P_{2017,2018,2019}<0.0001\right)$, yet the buffer $\times$ clone interaction governed health for all three years $\left(P_{2017}<0.0001 ; P_{2018}<0.0001 ; P_{2019}=0.0152\right)\left(\right.$ Table S2). $\mathrm{HEALTH}_{2017}$ of trees

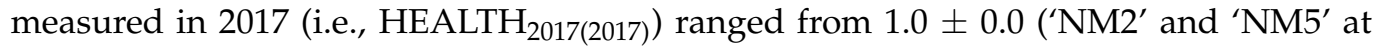
Menomonee Falls (East); 'NM2' at Whitelaw; most healthy] to $1.6 \pm 0.1$ ('DM114' at Caledonia (East); least healthy), with an overall mean of $1.1 \pm 0.1$ (Figure 2). Thus, all trees were of optimal health (i.e., health index ranging from 1 to 2 ). The healthiest trees were grown at Whitelaw, which had $14.1 \%$ better HEALTH 2017(2017) than at Caledonia (East), the buffer with trees exhibiting the poorest health. The range in health scores was broader for clones, with 'NM5' having 37.0\% healthier trees than 'DM114'. Common clones had the healthiest and Experimental clones the least-healthiest trees, with NRRI genotypes

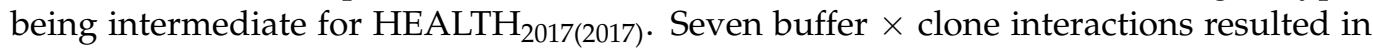
$\mathrm{HEALTH}_{2017(2017)}$ values that were significantly greater than the overall mean ['DM114', 'DN177', and 'NC14106' at Caledonia (East); 'DM114' and 'NC14106' at Menomonee Falls (East); 'DM114' at Menomonee Falls (West); 'DM114' at Slinger]. With the exception of

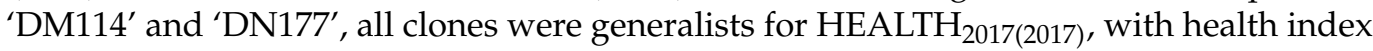
scores not varying by more than 0.3 for any buffer $\times$ clone combinations. Trees grown at Bellevue (West) and Whitelaw were 38.4\% healthier than those at Menomonee Falls (East) and Caledonia (East) for 'DM114'. Similarly, for 'DN177', trees at Whitelaw were $32.2 \%$ healthier than at Caledonia (East) (Figure 2). Trends in second- $\left(\mathrm{HEALTH}_{2017(2018)}\right)$ and third-year $\left(\mathrm{HEALTH}_{2017(2019)}\right)$ health of the 2017 buffer group trees were similar to $\mathrm{HEALTH}_{\text {2017(2017) }}$ (Figures S1 and S2). 


$\begin{array}{lll}\text { NRRI Clones } & \text { Experimental Clones } & \square \text { Common Clones } \\ \text { A: } 99038022 & \text { D: } 7300502 & \text { I: DN5 } \\ \text { B: } 99059016 & \text { E: DM114 } & \text { J: DN34 } \\ \text { C: } 9732-36 & \text { F: DN177 } & \text { K: NM2 } \\ & \text { G: NC14106 } & \text { L: NM6 } \\ & \text { H: NM5 } & \end{array}$
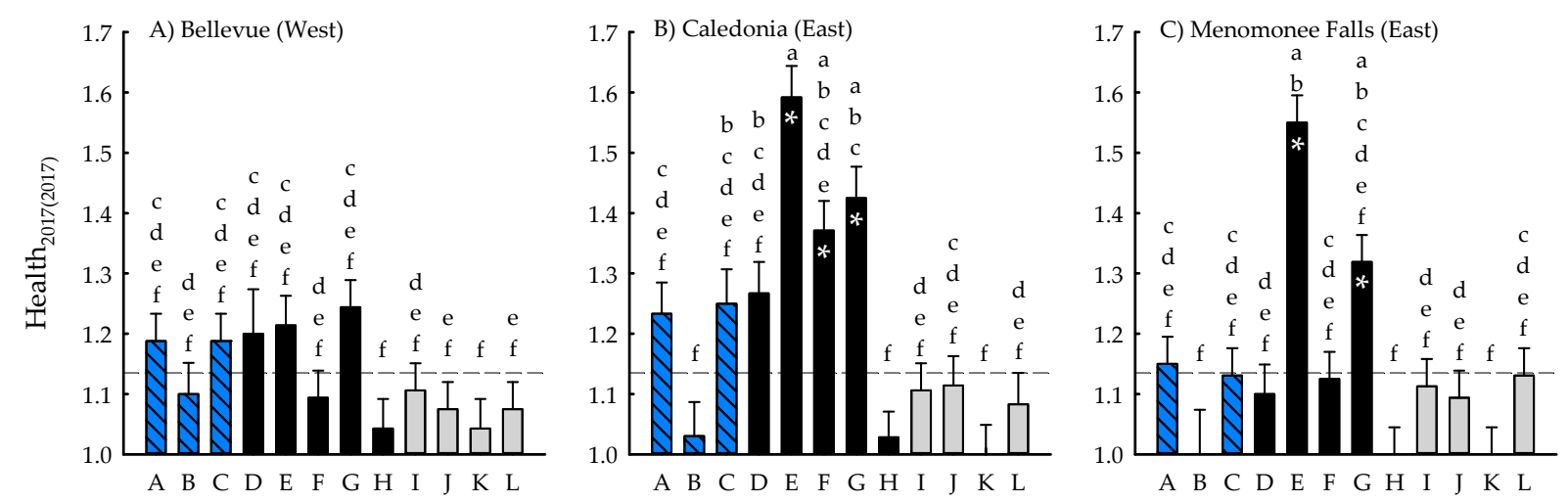

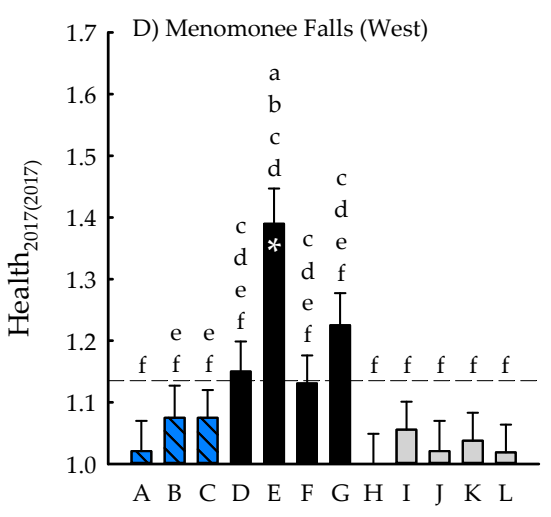

Clone

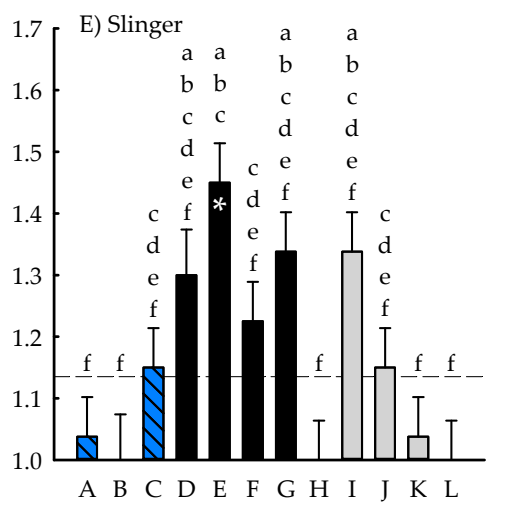

Clone

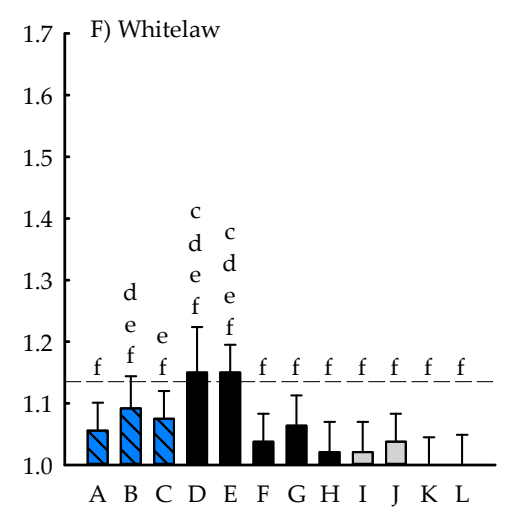

Clone

Figure 2. Tree health ( \pm one standard error) determined after the 2017 growing season of twelve poplar clones tested in six phytoremediation buffer systems (i.e., phyto buffers) (A-F) established in 2017 (i.e., the 2017 buffer group) in the Lake Michigan watershed of eastern Wisconsin, USA. The dashed line represents the overall mean, and asterisks indicate means different than the overall mean at $P<0.05$. Bars with different letters across all buffer $\times$ clone combinations are different at $P<0.05$. See Materials and Methods for complete tree health definitions $(1=$ optimal health, $2=$ good health, $3=$ moderate health, 4 = poor health, and $5=$ dead).

Differences among buffer and clone main effects were significant for first$\left(\right.$ HEALTH $\left._{2018(2018)}\right)$ and second-year $\left(\mathrm{HEALTH}_{2018(2019)}\right]$ health of the 2018 buffer group trees $\left(P_{2018}=0.0009\right.$ for Clone; $P_{2018,2019}<0.0001$ for all other main effects), yet the buffer $\times$ clone interaction governed health for both years $\left(P_{2018}=0.0029 ; P_{2019}<0.0001\right)$ (Table S2). $\mathrm{HEALTH}_{2018(2018)}$ ranged from $1.0 \pm 0.0$ ('9732-11', '9732-24', 'DM114', 'DN2', 'NM2', 'NM5', 'NM6' at Bellevue (East); '9732-11', 'DN2' at Bellevue (Central); most healthy) to $1.5 \pm 0.1$ ('DM114' at Manitowoc; least healthy), with an overall mean of $1.1 \pm 0.1$ (Figure 3).

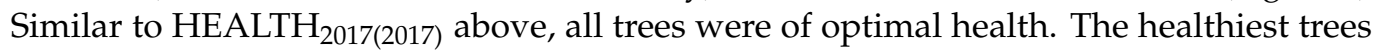
were grown at Marquette and Bellevue (East), which had $25.5 \%$ better $\mathrm{HEALTH}_{2018(2018)}$ than at Manitowoc that exhibited the poorest health. The range in health scores was narrower for clones, with 'NM5' having $12.9 \%$ healthier trees than 'DM114' that had the poorest health. Common and NRRI clones had the best overall health scores that were similar to one another yet better than Experimental genotypes. Seven buffer $\times$ clone interactions resulted in $\mathrm{HEALTH}_{2018(2018)}$ values there were significantly greater (i.e., of poorer health) than the overall mean, with all occurring at Manitowoc: '9732-11', '9732-24', '9732-31', '9732-36', '7300502', 'DM114', 'DN2', and 'DN5'. With the exception of '7300502'

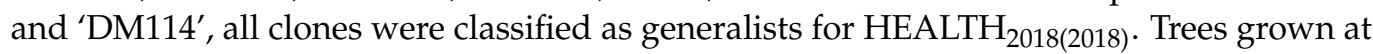


Bellevue (East) and Marquette were 52.5\% healthier than those at Manitowoc for '7300502', while those at Bellevue (East), Bellevue (Central), and Marquette were $48.8 \%$ healthier than at Manitowoc (Figure 3). Trends in second-year health of the 2018 buffer group trees $\left(\mathrm{HEALTH}_{2018(2019)}\right)$ were similar to $\mathrm{HEALTH}_{2018(2018)}$ (Figure S3).

$\begin{array}{lll}\text { NRRI Clones } & \text { Experimental Clones } & \square \text { Common Clones } \\ \text { A: } 9732-11 & \text { E: } 7300502 & \text { I: DN5 } \\ \text { B: } 9732-24 & \text { F: DM114 } & \text { J: DN34 } \\ \text { C: } 9732-31 & \text { G: DN2 } & \text { K: NM2 } \\ \text { D: } 9732-36 & \text { H: NM5 } & \text { L: NM6 }\end{array}$
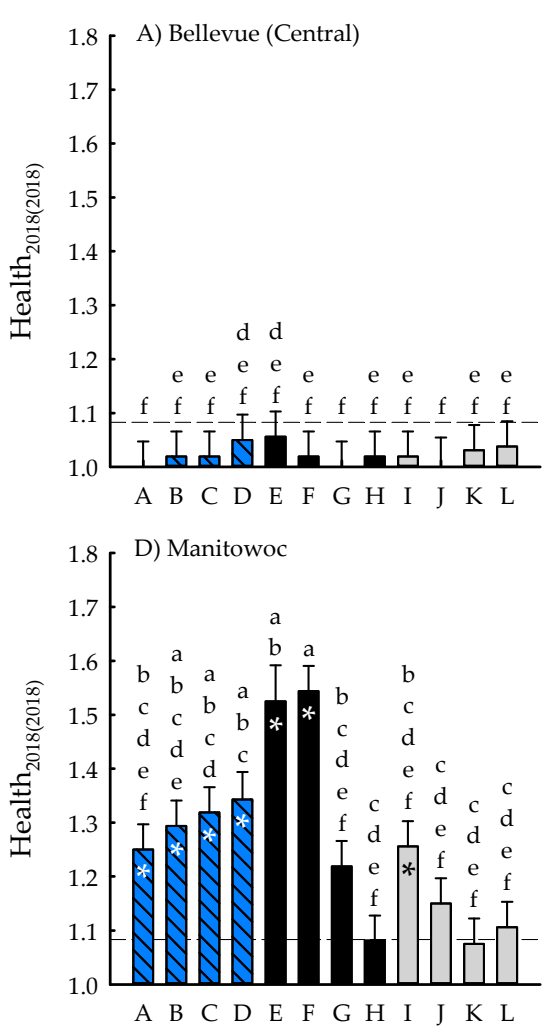

Clone
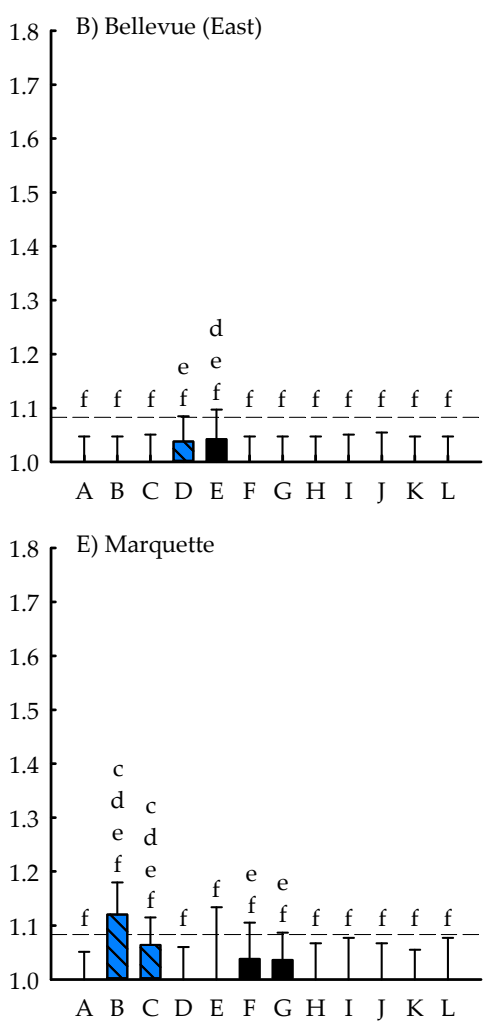

Clone

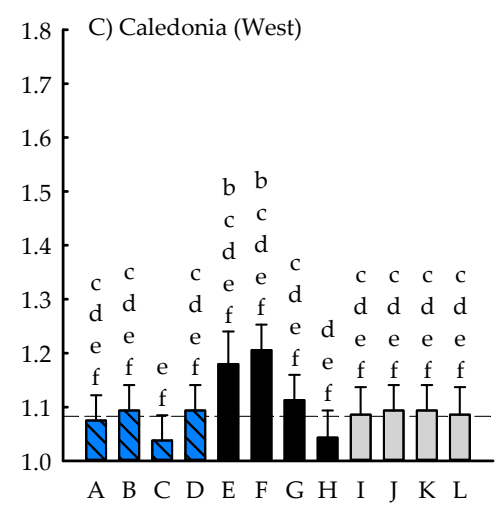

Clone

Figure 3. Tree health ( \pm one standard error) determined after the 2018 growing season of twelve poplar clones tested in five phytoremediation buffer systems (i.e., phyto buffers) (A-E) established in 2018 (i.e., the 2018 buffer group) in the Lake Superior watershed of the Upper Peninsula of Michigan, USA and the Lake Michigan watershed of eastern Wisconsin, USA. The dashed line represents the overall mean, and asterisks indicate means different than the overall mean at $P<0.05$. Bars with different letters across all buffer $\times$ clone combinations are different at $P<0.05$. See Materials and Methods for complete tree health definitions $(1=$ optimal health, $2=$ good health, $3=$ moderate health, $4=$ poor health, and $5=$ dead $)$.

Differences among buffer and clone main effects were significant for first-year health of the 2019 buffer group trees $\left(\mathrm{HEALTH}_{2019(2019)}\right)\left(P_{\text {Buffer }}<0.0001 ; P_{\text {Clone }}=0.0159\right)$, yet the buffer $\times$ clone interaction governed health $(P=0.0036)($ Table S2). HEALTH $2019(2019)$ ranged from $1.0 \pm 0.0$ ['9732-24', 'DM114', 'DN2', 'NM2', 'NM6' at Munising; '9732-31' at Ontonagon (North); '99038022', '9732-11', 'DM114', 'DN2', 'NM6' at Ontonagon (South); most healthy] to $1.3 \pm 0.0$ ['DM114', 'DN2' Escanaba (West); least healthy], with an overall mean of $1.1 \pm 0.0$ (Figure 4). All trees were of optimal health. The healthiest trees were grown at Ontonagon (South), which had $13.7 \%$ better HEALTH ${ }_{2019(2019)}$ than at Escanaba (West) where trees had the poorest health. The range in health scores was narrower for clones, with $7.2 \%$ separating the healthiest trees of 'NM2' from the least healthy trees of 'DN2', 'DN34', and 'DN177'. Similar to HEALTH $2017(2017)$, Common clones had the healthiest and Experimental clones the least-healthiest trees, with NRRI genotypes being intermediate 
for HEALTH 2019(2019). Two buffer $\times$ clone interactions resulted in HEALTH $_{2019(2019)}$ values there were significantly greater than the overall mean ('DM114' and 'DN2' at Escanaba (West)). No clones varied by more than 0.3 health index points for any buffer $\times$ clone combinations, thus indicating that all had generalist health performance. The largest variation in clonal responses to specific buffers was where trees were $21.7 \%$ healthier at all buffers relative to Escanaba (West) for 'DM114', and where trees were 26.3\% healthier at Munising and Ontonagon (South) than Escanaba (West) for 'DN2' (Figure 4).

$\begin{array}{lll}\text { NRRI Clones } & \text { Experimental Clones } & \square \text { Common Clones } \\ \text { A: } 99038022 & \text { F: DM114 } & \text { J: DN34 } \\ \text { B: } 9732-11 & \text { G: DN2 } & \text { K: NM2 } \\ \text { C: } 9732-24 & \text { H: DN177 } & \text { L: NM6 } \\ \text { D: } 9732-31 & \text { I: NM5 } & \\ \text { E: } 9732-36 & & \end{array}$

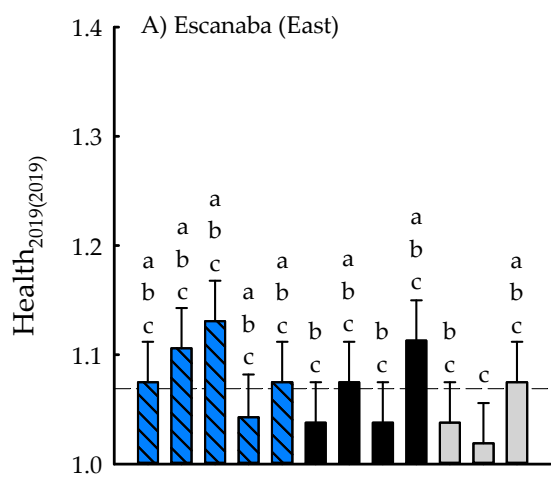

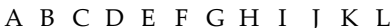

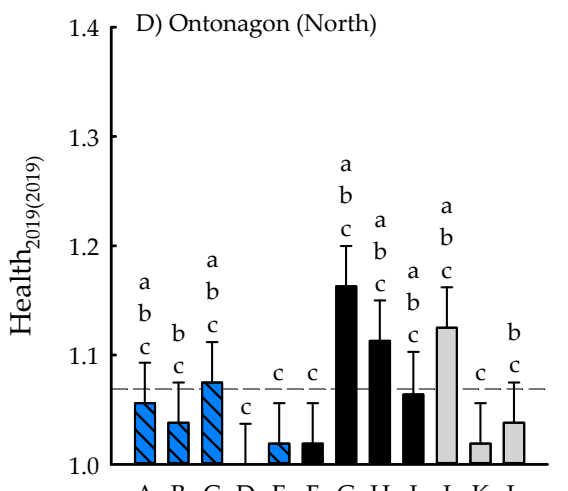

Clone

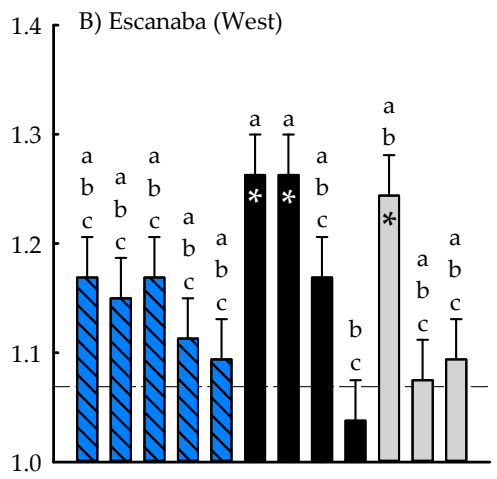

A B C D E F G H I J K L

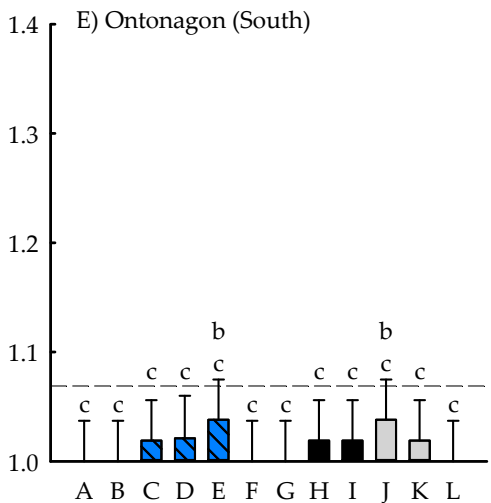

Clone

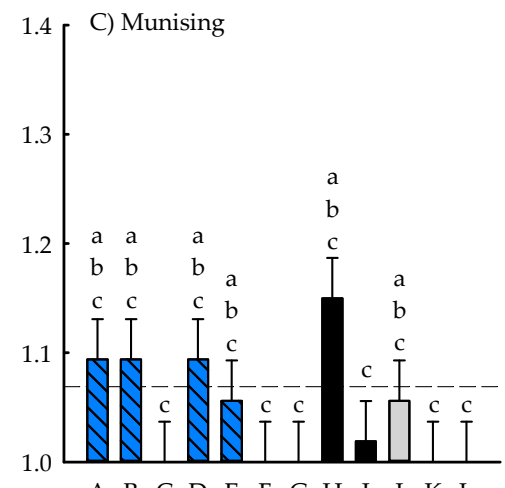

Clone

Figure 4. Tree health ( \pm one standard error) determined after the 2019 growing season of twelve poplar clones tested in five phytoremediation buffer systems (i.e., phyto buffers) (A-E) established in 2019 (i.e., the 2019 buffer group) in the Lake Superior watershed of the Upper Peninsula of Michigan, USA. The dashed line represents the overall mean, and asterisks indicate means different than the overall mean at $P<0.05$. Bars with different letters across all buffer $\times$ clone combinations are different at $P<0.05$. See Materials and Methods for complete tree health definitions $(1=$ optimal health, $2=$ good health, $3=$ moderate health, $4=$ poor health, and $5=$ dead).

\subsection{Biomass and Growth}

Differences for buffer and clone main effects were significant for fourth-year mean annual increment of the 2017 buffer group trees $\left(\mathrm{MAI}_{2017(2020)}\right)(P<0.0001)$, yet the buffer $\times$ clone interaction governed $\mathrm{MAI}_{2017(2020)}(P<0.0001)$ (Table S2). $\mathrm{MAI}_{2017(2020)}$ ranged from $1.10 \pm 0.73$ ('7300502' at Whitelaw) to $7.67 \pm 0.5 \mathrm{Mg} \mathrm{ha}^{-1} \mathrm{yr}^{-1}$ ('NM5' at Menomonee Falls (East)), with an overall mean of $3.20 \pm 0.51 \mathrm{Mg} \mathrm{ha}^{-1} \mathrm{yr}^{-1}$ (Figure 5). The largest trees were grown at Menomonee Falls (West), which had 55.4\% greater MAI $2017(2020)$ than at Whitelaw, the buffer with the smallest trees. The range in $\mathrm{MAI}_{2017(2020)}$ was broader for clones, with 
'NM5' exhibiting 69.8\% more biomass than 'NC14106' that had the smallest trees of any genotype. While $\mathrm{MAI}_{2017(2020)}$ varied across genotypes, trends across clone groups were non-existent, with Common, Experimental, and NRRI clones performing similarly across buffer $\times$ clone combinations. Many buffer $\times$ clone interactions resulted in $\mathrm{MAI}_{2017(2020)}$ values that were significantly greater than the overall mean, with the most notable being 'NM5' outperforming the mean at four of the six buffers: Caledonia (East), Menomonee Falls (East), Menomonee Falls (West), and Slinger. In contrast, 'NC14106' had significantly less $\mathrm{MAI}_{2017(2020)}$ than the overall mean at three buffers: Bellevue (West), Menomonee Falls (East), and Whitelaw.

$\begin{array}{lll}\text { NRRI Clones } & \text { Experimental Clones } & \square \text { Common Clones } \\ \text { A: } 99038022 & \text { D: } 7300502 & \text { I: DN5 } \\ \text { B: } 99059016 & \text { E: DM114 } & \text { J: DN34 } \\ \text { C: } 9732-36 & \text { F: DN177 } & \text { K: NM2 } \\ & \text { G: NC14106 } & \text { L: NM6 } \\ & \text { H: NM5 } & \end{array}$
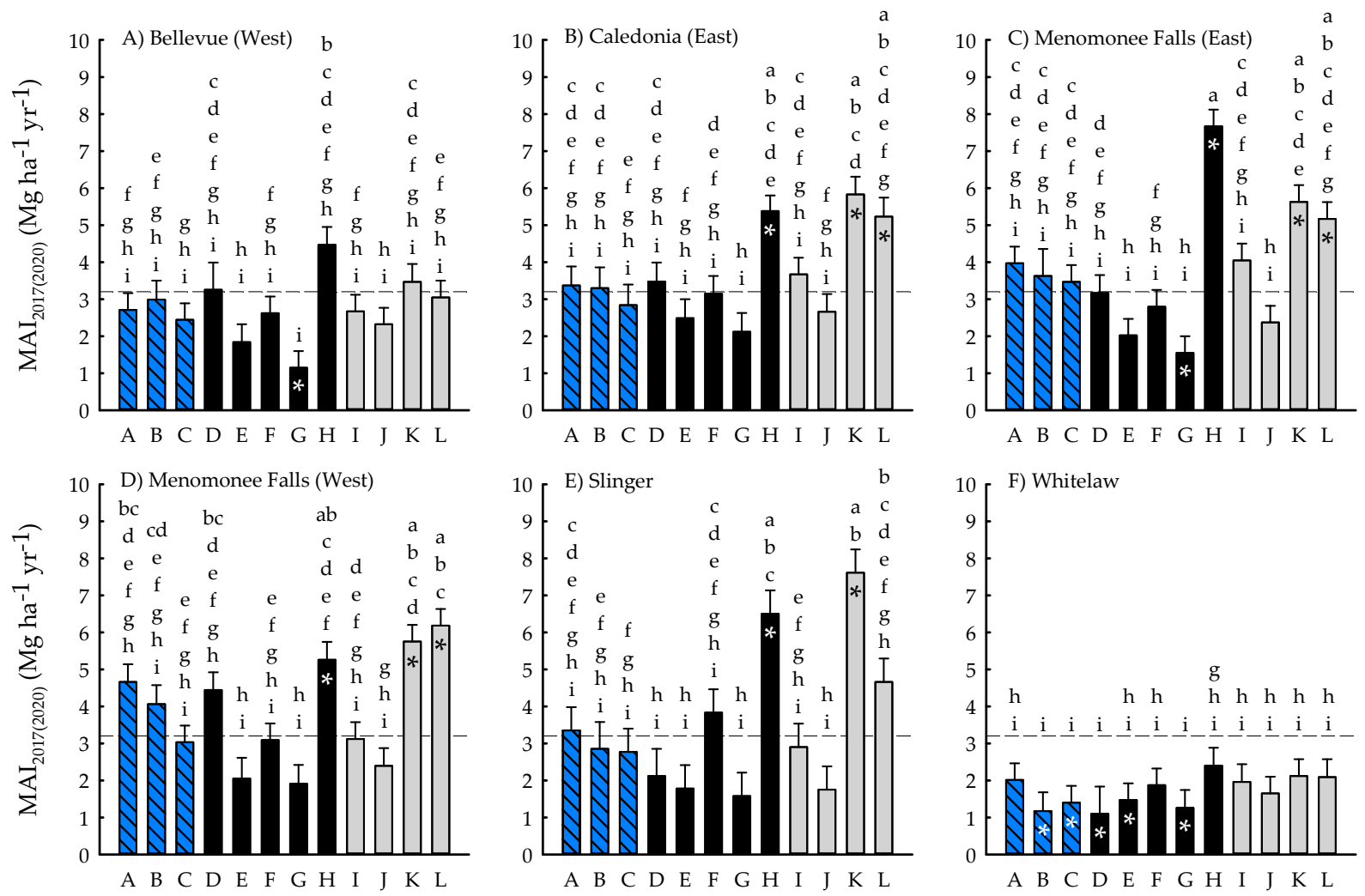

Clone

Clone

Clone

Figure 5. Mean annual increment $\left(\mathrm{Mg} \mathrm{ha}^{-1} \mathrm{yr}^{-1}\right)$ ( \pm one standard error) determined after the 2020 growing season of twelve poplar clones tested in six phytoremediation buffer systems (i.e., phyto buffers) (A-F) established in 2017 (i.e., the 2017 buffer group) in the Lake Michigan watershed of eastern Wisconsin, USA. The dashed line represents the overall mean, and asterisks indicate means different than the overall mean at $P<0.05$. Bars with different letters across all buffer $\times$ clone combinations are different at $P<0.05$.

In addition to these changes in magnitude, there were distinct changes in $\mathrm{MAI}_{2017(2020)}$ ranks that defined the genotypes as generalists or specialists. In particular, clones exhibited generalist $\mathrm{MAI}_{2017(2020)}$, with four exceptions (Table 4). First, '99059016' had stable performance across five of the six buffers, with Whitelaw (i.e., the buffer with its lowest rank of eleventh) having 60.9\% less MAI $2017(2020)$ than Bellevue (West), where '99059016' ranked fifth. Second, '7300502' had broad variation in $\mathrm{MAI}_{2017(2020)}$ across all six buffers, with a $75.3 \%$ reduction in $\mathrm{MAI}_{2017(2020)}$ at Whitelaw (rank $=12$ ) versus Bellevue (West) (rank $=3$ ). Third, 'DN177' was a specialist because of its high MAI $_{2017(2020)}$ at Slinger (where it ranked 
fourth), which was 36.7\% greater than Menomonee Falls (East) (rank =9). Fourth, despite higher ranking (rank =7) at Whitelaw relative to other buffers for 'DN34', $\mathrm{MAI}_{2017(2020)}$ at Whitelaw was $60.6 \%$ less than that of Caledonia (East) (rank $=11$ ), resulting in its specialist response (Table 4). However, this classification for 'DN34' should be interpreted with caution, especially given that 'DN34' ranked tenth at four buffers and eleventh at one buffer, indicating stable performance across buffers.

Table 4. Clonal rank for mean annual increment (MAI2017(2020)) measured after the fourth growing season of twelve poplar clones tested in six phytoremediation buffer systems (i.e., phyto buffers) established in 2017 (i.e., the 2017 buffer group) in the Lake Michigan watershed of eastern Wisconsin, USA.

\begin{tabular}{cccccccc}
\hline & & & \multicolumn{5}{c}{ Phyto Buffer $^{\text {a }}$} \\
\hline Clone & $\begin{array}{c}\text { Response } \\
\text { Group }\end{array}$ & BW & CE & ME & MW & SL & WH \\
\hline 99038022 & Generalist & 6 & 6 & 5 & 4 & 5 & 4 \\
99059016 & Specialist & 5 & 7 & 6 & 6 & 7 & 11 \\
$9732-36$ & Generalist & 9 & 9 & 7 & 9 & 8 & 9 \\
7300502 & Specialist & 3 & 5 & 8 & 5 & 9 & 12 \\
DM114 & Generalist & 11 & 11 & 11 & 11 & 10 & 8 \\
DN177 & Specialist & 8 & 8 & 9 & 8 & 4 & 6 \\
NC14106 & Generalist & 12 & 12 & 12 & 12 & 12 & 10 \\
NM5 & Generalist & 1 & 2 & 1 & 3 & 2 & 1 \\
DN5 & Generalist & 7 & 4 & 4 & 7 & 6 & 5 \\
DN34 & Specialist & 10 & 10 & 10 & 10 & 11 & 7 \\
NM2 & Generalist & 2 & 1 & 2 & 2 & 1 & 2 \\
NM6 & Generalist & 4 & 3 & 3 & 1 & 3 & 3
\end{tabular}

a BW: Bellevue (West); CE: Caledonia (East); ME: Menomonee Falls (East); MW: Menomonee Falls (West); SL: Slinger; $W H$ : Whitelaw. ${ }^{b}$ Generalist $=$ clone exhibiting stable $\mathrm{MAI}_{2017(2020)}$ across phyto buffers (i.e., minimal rank changes); Specialist $=$ clone exhibiting exceptional $\mathrm{MAI}_{2017(2020)}$ at one or more phyto buffers relative to the other buffers (i.e., broad rank changes).

The buffer $\times$ clone $\times$ year interaction was significant for height $(P=0.0483)$, diameter $(P=0.0018)$, and volume $(P=0.0001)$ of the 2017 buffer group trees (Table S3). VOLUME $_{2017}$ of trees measured in $2017\left(\right.$ VOLUME $\left._{2017(2017)}\right)$ ranged from $3.1 \pm 54.4$ ('7300502' at Whitelaw) to $459.6 \pm 22.6 \mathrm{~cm}^{3}$ ('7300502' at Slinger), with an overall mean of $132.0 \pm 38.7 \mathrm{~cm}^{3}$, while VOLUME $2017(2018)$ (i.e., 2017 buffer group trees measured in 2018) ranged from $503.5 \pm 1619.6$ ('7300502' at Whitelaw) to $13,027.0 \pm 1402.6 \mathrm{~cm}^{3}$ ('NM2' at Slinger), with an overall mean of $5765.2 \pm 1132.3 \mathrm{~cm}^{3}$ (Table 5). VOLUME $2017(2019)$ ranged from $1668.7 \pm 3018.1$ ('7300502' at Whitelaw) to 26,652.0 $\pm 1848.0 \mathrm{~cm}^{3}$ ('NM5' at Menomonee Falls (East)), with an overall mean of 10,530.6 $\pm 2109.5 \mathrm{~cm}^{3}$ (Table 5). Across all buffer $\times$ clone $\times$ year combinations, volume increased 43.7 -fold from the first year to the second year after planting, and then 1.8-fold from the second year to the third year. After the first and second growing seasons, the largest trees were grown at Slinger, which had 1301 and 268\% greater volume than the buffer with the smallest trees (Whitelaw), respectively. For the third growing season, trees at Menomonee Falls (East) were largest, with $\operatorname{VOLUME}_{2017(2019)}$ being $338 \%$ greater than Whitelaw, which had the smallest trees.

The range in volume was narrower for clones, with 'DN5' having 204\% greater volume than the least productive clone ('99059016') for $\mathrm{VOLUME}_{2017(2017)}$, 'NM5' being $86 \%$ greater than '7300502' for VOLUME $2017(2018)$, and 'NM5' being $114 \%$ greater than 'NC14106' for VOLUME $_{2017(2019)}$. With the exception of the first growing season where NRRI clones exhibited the least overall volume followed by Experimental and Common (most volume) genotypes, Common clones had the largest and Experimental clones the smallest trees, with NRRI genotypes being intermediate for VOLUME $2017(2018)$ and VOLUME $2017(2019)$. Trends in height and diameter of the 2017 buffer group trees were similar to volume (Tables S4 and S5). Furthermore, in addition to the broad variability in the magnitude of differences among buffer $\times$ clone $\times$ year combinations, the frequency and magnitude of changes in rank within and across years defined genotypes as generalists (i.e., minimal rank changes) 
or specialists (i.e., broad variation resulting in $\geq 5$ rank changes for at least one buffer $\times$ clone $\times$ year pair) (Table S6). In particular, the NRRI clones ('99038022', '99059016', '9732-36') were high-level generalists characterized by nearly universal stability in ranks across buffers within measurement years, less than three substantial (i.e., $>5$ ranks) rank changes across all three-way combinations, and moderate to high rank stability over time. Clones 'DM114' and 'NC14106' were also generalists, exhibiting moderate rank stability within years and consistent ranks over time. The remaining genotypes were specialists. Clone '7300502' had the most variability in early ranks of all clones, followed by high rank stability in later years that were not consistent over time. For example, '7300502' ranked first at Slinger in 2017 but then twelfth at this buffer in 2018 and 2019. Clones 'NM2', 'NM5', and 'NM6' were high-level specialists characterized by broad variability in ranks across buffers within measurement years, frequent substantial rank changes across all three-way combinations, and moderate stability over time. Similarly, 'DN5', 'DN34', and 'DN177' were specialists, albeit with more moderate rank variation than the 'NMx' genotypes (Table S6).

Table 5. Volume $\left(\mathrm{cm}^{3}\right)$ ( \pm one standard error) of twelve poplar clones tested in six phytoremediation buffer systems (i.e., phyto buffers) established in 2017 (i.e., the 2017 buffer group) in the Lake Michigan watershed of eastern Wisconsin, USA. Trees were measured following the 2017, 2018, and 2019 growing seasons. Volume values with different letters within a clone column across measurement years are different at $P<0.05$.

\begin{tabular}{|c|c|c|c|c|c|c|c|c|c|c|c|c|}
\hline \multirow[b]{2}{*}{ Buffer $^{a}$} & \multicolumn{12}{|c|}{ Clone } \\
\hline & \multicolumn{2}{|l|}{99038022} & \multicolumn{2}{|l|}{99059016} & \multicolumn{2}{|l|}{ 9732-36 } & \multicolumn{2}{|l|}{7300502} & \multicolumn{2}{|l|}{ DM114 } & \multicolumn{2}{|l|}{ DN177 } \\
\hline & \multicolumn{12}{|c|}{2017 Measurement year } \\
\hline BW & $51 \pm 34$ & $\mathrm{i}$ & $14 \pm 38$ & $\mathrm{v}$ & $26 \pm 33$ & $\mathrm{i}$ & $29 \pm 54$ & $\mathrm{w}$ & $32 \pm 39$ & gh & $29 \pm 34$ & $\mathrm{~s}$ \\
\hline $\mathrm{CE}$ & $74 \pm 41$ & $\mathrm{i}$ & $56 \pm 42$ & $\mathrm{v}$ & $101 \pm 42$ & i & $137 \pm 38$ & $\mathrm{w}$ & $100 \pm 39$ & fgh & $154 \pm 36$ & $t$ \\
\hline ME & $199 \pm 36$ & $\mathrm{~h}$ & $78 \pm 54$ & $\mathrm{v}$ & $180 \pm 34$ & i & $128 \pm 28$ & $\mathrm{w}$ & $168 \pm 38$ & $\mathrm{f}$ & $188 \pm 34$ & $t$ \\
\hline MW & $247 \pm 38$ & gh & $48 \pm 44$ & $\mathrm{v}$ & $106 \pm 23$ & $\mathrm{i}$ & $203 \pm 27$ & $\mathrm{w}$ & $130 \pm 44$ & $\mathrm{fg}$ & $143 \pm 41$ & $\mathrm{t}$ \\
\hline SL & $359 \pm 64$ & $\mathrm{~g}$ & $109 \pm 47$ & wv & $250 \pm 42$ & $\mathrm{i}$ & $460 \pm 23$ & $\mathrm{w}$ & $279 \pm 42$ & e & $337 \pm 47$ & $\mathrm{u}$ \\
\hline WH & $39 \pm 33$ & $\mathrm{i}$ & $13 \pm 38$ & $\mathrm{v}$ & $27 \pm 33$ & $\begin{array}{c}\mathrm{i} \\
8 \text { Meast }\end{array}$ & $\begin{array}{c}3 \pm 54 \\
\text { rement year }\end{array}$ & $\mathrm{w}$ & $26 \pm 35$ & $\mathrm{~h}$ & $17 \pm 34$ & $\mathrm{~s}$ \\
\hline BW & $6412 \pm 992$ & de & $4859 \pm 1145$ & $\mathrm{yx}$ & $4221 \pm 992$ & fgh & $2323 \pm 1620$ & $\mathrm{w}$ & $3559 \pm 1060$ & $\mathrm{~cd}$ & $4748 \pm 992$ & wV \\
\hline $\mathrm{CE}$ & $5084 \pm 1145$ & ef & $6080 \pm 1255$ & $\mathrm{yx}$ & $5653 \pm 1254$ & efg & $4702 \pm 1145$ & $\mathrm{xw}$ & $5204 \pm 1145$ & bcd & $6303 \pm 1060$ & $\mathrm{xw}$ \\
\hline ME & $8719 \pm 992$ & bcd & $8800 \pm 1620$ & $\mathrm{y}$ & $8305 \pm 992$ & bcde & $4599 \pm 1060$ & $\mathrm{xw}$ & $5663 \pm 992$ & $\mathrm{bc}$ & $7861 \pm 992$ & $x$ \\
\hline MW & $9423 \pm 1060$ & bc & $8780 \pm 1145$ & $\mathrm{y}$ & $6579 \pm 992$ & defg & $6418 \pm 1060$ & $\mathrm{yx}$ & $6105 \pm 1254$ & $a b c$ & $7842 \pm 992$ & $x$ \\
\hline SL & $8076 \pm 1403$ & cde & $7336 \pm 1619$ & $\mathrm{yx}$ & $7327 \pm 1403$ & cdef & $3520 \pm 1620$ & $\mathrm{xW}$ & $5383 \pm 1403$ & bcd & $9714 \pm 1402$ & $\mathrm{yx}$ \\
\hline \multirow[t]{2}{*}{ WH } & $3286 \pm 992$ & $\mathrm{f}$ & $1454 \pm 1145$ & wV & $1852 \pm 992$ & hi & $504 \pm 1620$ & $w$ & $2230 \pm 992$ & $\mathrm{~d}$ & $2396 \pm 992$ & $\mathrm{v}$ \\
\hline & \multicolumn{12}{|c|}{2019 Measurement year } \\
\hline BW & $7837 \pm 1848$ & cde & $8008 \pm 2134$ & $\mathrm{yx}$ & $7026 \pm 1848$ & cdefg & $6827 \pm 3018$ & $\mathrm{yx}$ & $6622 \pm 1976$ & $a b c$ & $9900 \pm 1848$ & $\mathrm{yx}$ \\
\hline $\mathrm{CE}$ & $11,140 \pm 2134$ & $\mathrm{bc}$ & $10,301 \pm 2338$ & zy & $10,429 \pm 2338$ & abcd & $9992 \pm 2134$ & zy & $10,684 \pm 2134$ & a & $12,331 \pm 1976$ & $\mathrm{y}$ \\
\hline ME & $17,228 \pm 1848$ & a & $14,235 \pm 3018$ & $\mathrm{Z}$ & $15,618 \pm 1848$ & a & $9834 \pm 1976$ & zy & $9903 \pm 1848$ & a & $13,598 \pm 1848$ & $\mathrm{y}$ \\
\hline MW & $17,490 \pm 1976$ & $\mathrm{a}$ & $14,740 \pm 2134$ & $\mathrm{z}$ & $11,408 \pm 1849$ & $\mathrm{abc}$ & $14,137 \pm 1976$ & $\mathrm{z}$ & $8800 \pm 2338$ & $\mathrm{ab}$ & $12,334 \pm 1848$ & $\mathrm{y}$ \\
\hline SL & $14,022 \pm 2614$ & $a b$ & $10,795 \pm 3018$ & zy & $12,544 \pm 2614$ & $a b$ & $5379 \pm 3018$ & yxw & $8762 \pm 2613$ & $a b c$ & $20,272 \pm 2614$ & $\mathrm{z}$ \\
\hline WH & $4834 \pm 1848$ & ef & $2393 \pm 2134$ & XW & $2770 \pm 1848$ & ghi & $1669 \pm 3018$ & $\mathrm{w}$ & $3909 \pm 1848$ & bcd & $4960 \pm 1848$ & $\mathrm{xW}$ \\
\hline \multirow[t]{2}{*}{ Buffer } & NC14106 & & NM5 & & DN5 & & DN34 & & NM2 & & NM6 & \\
\hline & \multicolumn{12}{|c|}{2017 Measurement year } \\
\hline BW & $32 \pm 33$ & $\mathrm{~d}$ & $70 \pm 44$ & $\mathrm{qp}$ & $34 \pm 32$ & j & $27 \pm 34$ & $\mathrm{~s}$ & $45 \pm 36$ & e & $24 \pm 33$ & $\mathrm{v}$ \\
\hline $\mathrm{CE}$ & $69 \pm 38$ & $\mathrm{~d}$ & $68 \pm 36$ & $\mathrm{qp}$ & $184 \pm 32$ & i & $108 \pm 36$ & ts & $159 \pm 36$ & $\mathrm{e}$ & $114 \pm 38$ & $\mathrm{v}$ \\
\hline $\mathrm{ME}$ & $115 \pm 33$ & d & $269 \pm 41$ & $\mathrm{r}$ & $182 \pm 32$ & $\mathrm{i}$ & $190 \pm 34$ & ut & $121 \pm 33$ & e & $202 \pm 33$ & $\mathrm{v}$ \\
\hline MW & $93 \pm 38$ & $\mathrm{~d}$ & $133 \pm 44$ & $\mathrm{q}$ & $118 \pm 47$ & ij & $140 \pm 36$ & $t$ & $169 \pm 34$ & $\mathrm{e}$ & $151 \pm 33$ & $\mathrm{v}$ \\
\hline SL & $245 \pm 48$ & $\mathrm{~d}$ & $330 \pm 57$ & $\begin{array}{l}\mathrm{q} \\
\mathrm{r}\end{array}$ & $409 \pm 51$ & $\mathrm{~h}$ & $276 \pm 51$ & $\mathrm{u}$ & $415 \pm 47$ & e & $323 \pm 47$ & $\mathrm{v}$ \\
\hline WH & $18 \pm 36$ & d & $20 \pm 43$ & $\mathrm{p}$ & $42 \pm 34$ & j & $24 \pm 34$ & $\mathrm{~s}$ & $18 \pm 34$ & $\mathrm{e}$ & $22 \pm 36$ & $\mathrm{v}$ \\
\hline \multicolumn{13}{|c|}{2018 Measurement year } \\
\hline BW & $2675 \pm 992$ & c & $6631 \pm 1060$ & ut & $5872 \pm 992$ & efg & $6424 \pm 992$ & $\mathrm{xw}$ & $4820 \pm 1060$ & $\mathrm{~d}$ & $3399 \pm 992$ & $\mathrm{w}$ \\
\hline $\mathrm{CE}$ & $3951 \pm 1145$ & $\mathrm{Bc}$ & $4398 \pm 669$ & ts & $6646 \pm 992$ & efg & $5988 \pm 1060$ & xw & $6071 \pm 1060$ & cd & $5337 \pm 1145$ & $\mathrm{xw}$ \\
\hline ME & $4340 \pm 992$ & $\mathrm{bc}$ & $10,815 \pm 992$ & yv & $8521 \pm 992$ & cde & $7185 \pm 992$ & yxw & $6296 \pm 992$ & $\mathrm{~cd}$ & $6517 \pm 992$ & $\mathrm{x}$ \\
\hline MW & $5300 \pm 1145$ & $\mathrm{abc}$ & $6875 \pm 1060$ & $\mathrm{vu}$ & $7869 \pm 992$ & def & $8656 \pm 1060$ & $\mathrm{yx}$ & $8644 \pm 992$ & $\mathrm{c}$ & $7505 \pm 992$ & $\mathrm{yx}$ \\
\hline SL & $5102 \pm 1403$ & $\mathrm{abc}$ & $10,229 \pm 1402$ & $\mathrm{v}$ & $6930 \pm 1403$ & efg & $7040 \pm 1402$ & Xw & $13,027 \pm 1403$ & $\mathrm{~b}$ & $7628 \pm 1403$ & $\mathrm{yx}$ \\
\hline $\mathrm{WH}$ & $1815 \pm 1060$ & $\mathrm{~cd}$ & $2129 \pm 1060$ & s & $3422 \pm 1060$ & g & $2605 \pm 992$ & $\mathrm{v}$ & $1567 \pm 992$ & $\mathrm{e}$ & $1548 \pm 1060$ & WV \\
\hline \multicolumn{13}{|c|}{2019 Measurement year } \\
\hline BW & $4568 \pm 1848$ & $a b c$ & $11,230 \pm 1976$ & yv & $6959 \pm 1848$ & defg & $7644 \pm 1848$ & yxw & $8281 \pm 1976$ & c & $6106 \pm 1848$ & $x$ \\
\hline $\mathrm{CE}$ & $9496 \pm 2134$ & a & $10,632 \pm 1203$ & $\mathrm{~V}$ & $12,763 \pm 1848$ & $\mathrm{ab}$ & $9440 \pm 1976$ & zy & $15,705 \pm 1976$ & $\mathrm{~b}$ & $11,155 \pm 2134$ & zy \\
\hline ME & $7928 \pm 1848$ & $\mathrm{ab}$ & $26,652 \pm 1848$ & $\mathrm{z}$ & $17,335 \pm 1848$ & a & $13,068 \pm 1848$ & $\mathrm{z}$ & $15,887 \pm 1848$ & $\mathrm{~b}$ & $14,848 \pm 1848$ & $\mathrm{z}$ \\
\hline MW & $8497 \pm 2134$ & $\mathrm{ab}$ & $13,425 \pm 1976$ & $\mathrm{y}$ & $12,108 \pm 1848$ & $\mathrm{bc}$ & $9817 \pm 1976$ & zy & $15,186 \pm 1848$ & $\mathrm{~b}$ & $13,598 \pm 1848$ & $\mathrm{z}$ \\
\hline SL & $7720 \pm 2614$ & $a b c$ & $23,814 \pm 2614$ & $\mathrm{z}$ & $11,875 \pm 2613$ & bcd & $10,255 \pm 2614$ & zy & $26,238 \pm 2614$ & $\mathrm{a}$ & $13,526 \pm 2614$ & $\mathrm{z}$ \\
\hline WH & $3344 \pm 1976$ & $\mathrm{bc}$ & $3051 \pm 1976$ & ts & $3982 \pm 1976$ & $\mathrm{fg}$ & $4076 \pm 1848$ & wV & $2812 \pm 1848$ & de & $2448 \pm 1976$ & wV \\
\hline
\end{tabular}

${ }^{a}$ BW: Bellevue (West); CE: Caledonia (East); ME: Menomonee Falls (East); MW: Menomonee Falls (West); SL: Slinger; WH: Whitelaw. 
The buffer $\times$ clone $\times$ year interaction was significant for height, diameter, and volume $(P<0.0001)$ of the 2018 buffer group trees (Table S3). VOLUME 2018 (2018) ranged from $12.2 \pm 38.4$ ('DN5' at Marquette) to $185.7 \pm 25.3 \mathrm{~cm}^{3}$ ('NM2' at Manitowoc), with an overall mean of $71.2 \pm 26.3 \mathrm{~cm}^{3}$, while VOLUME 2018 (2019) ranged from $287.8 \pm 1518.7$ ('DN5' at Marquette) to $11,085.0 \pm 930.0 \mathrm{~cm}^{3}$ ('NM2' at Manitowoc), with an overall mean of $3418.4 \pm 1035.2 \mathrm{~cm}^{3}$ (Table 6). VOLUME 2018 (2020) ranged from $261.0 \pm 3882.2$ ('DN5' at Marquette) to $27,220.0 \pm 2377.4 \mathrm{~cm}^{3}$ ('NM5' at Manitowoc), with an overall mean of $8826.0 \pm 2646.2 \mathrm{~cm}^{3}$ (Table 6). Across all buffer $\times$ clone $\times$ year combinations, volume increased 48-fold from the first year to the second year after planting, and then 2.6-fold from the second year to the third year. After the first growing season, the largest trees were grown at Caledonia (West), which had 529\% greater volume than Marquette, the buffer with the smallest trees. During the second and third growing seasons, the largest trees were from Manitowoc, which had 1079 and $1744 \%$ greater volume than the buffer with the smallest trees (Marquette), respectively. As with volume for the 2017 buffer group trees, there was less variability among clones than buffers, with '9732-31' having 156\% greater volume than the least productive clone ('7300502') for VOLUME $2018(2018)$, 'NM5' being 163\% greater than '7300502' for VOLUME 2018 (2018), and 'NM5' being 143\% greater than 'DM114' for VOLUME $_{2018(2018)}$. During the first growing season, NRRI clones had the greatest overall volume, while Common clones exhibited the largest trees at two and three years after planting. For all three years, Experimental clones had the least volume. Trends in height and diameter of the 2018 buffer group trees were similar to volume (Tables S7 and S8). Moreover, as with 2017 buffer group trees, changes in magnitude and rank of 2018 buffer group clones across buffer $\times$ year combinations defined them as generalists or specialists (defined as for Table S6 above) (Table S9). Similar to 2017, the NRRI clones ('9732-11', '9732-24', '9732-31', '9732-36') were high-level generalists with universal stability in ranks, few rank changes greater than five ranks, and high rank stability over time. Clone 'DM114' was also a generalist, having only two substantial rank changes and nearly identical ranks from 2017 to 2019. All other genotypes were specialists. As in 2017, clone '7300502' had a high level of early rank variability and low to moderate rank consistency over time; clones 'NM2', 'NM5', and 'NM6' were high-level specialists with broad rank variability, numerous substantial rank changes, and moderate stability as trees aged; 'DN2', 'DN5', and 'DN34' were consistent specialists with moderate levels of rank changes and age-dependent stability (Table S9).

The buffer $\times$ clone $\times$ year interaction was significant for height $(P=0.0079)$, diameter $(P<0.0001)$, and volume $(P<0.0001)$ of the 2019 buffer group trees (Table S3). VOLUME $_{2019(2019)}$ ranged from $8.6 \pm 26.9$ ('DN177' at Ontonagon (North)) to 396. $\pm 26.7 \mathrm{~cm}^{3}$ ('99038022' at Escanaba (West)), with an overall mean of $88.7 \pm 26.7 \mathrm{~cm}^{3}$, while VOLUME $_{2019(2020)}$ ranged from $92.6 \pm 612.7$ ('NM5' at Ontonagon (North)) to 8909.6 $\pm 573.1 \mathrm{~cm}^{3}$ ('NM2' at Escanaba (West)), with an overall mean of $1440.4 \pm 575.1 \mathrm{~cm}^{3}$ (Table 7). Across all buffer $\times$ clone $\times$ year combinations, volume increased 16.2-fold from the first year to the second year after planting. After the first and second growing seasons, the largest trees were grown at Escanaba (West), which had 1008 and 1066\% greater volume than the buffer with the smallest trees (Ontonagon (North)), respectively. For VOLUME $_{2019(2019)}$ ' '99038022' had 101\% greater volume than the least productive clone ('DN177'), while 'NM2' was 164\% greater than '9732-11' for VOLUME 2019 (2020). NRRI clones exhibited the greatest first-year volume, followed by Common and Experimental genotypes. For VOLUME 2019 (2020), ranks of NRRI, Experimental, and Common clones changed, with Common genotypes having the most VOLUME 2019 (2020) followed by Experimental and NRRI (least volume) clones. Trends in height and diameter of the 2019 buffer group trees were similar to volume (Tables S10 and S11). Furthermore, 2019 clones were classified as generalists or specialists (defined as for Table S6 above) (Table S12). 
Table 6. Volume $\left(\mathrm{cm}^{3}\right)$ ( \pm one standard error) of twelve poplar clones tested in five phytoremediation buffer systems (i.e., phyto buffers) established in 2018 (i.e., the 2018 buffer group) in the Lake Superior watershed of the Upper Peninsula of Michigan, USA and the Lake Michigan watershed of eastern Wisconsin, USA. Trees were measured following the 2018, 2019 , and 2020 growing seasons. Volume values with different letters within a clone column across measurement years are different at $P<0.05$.

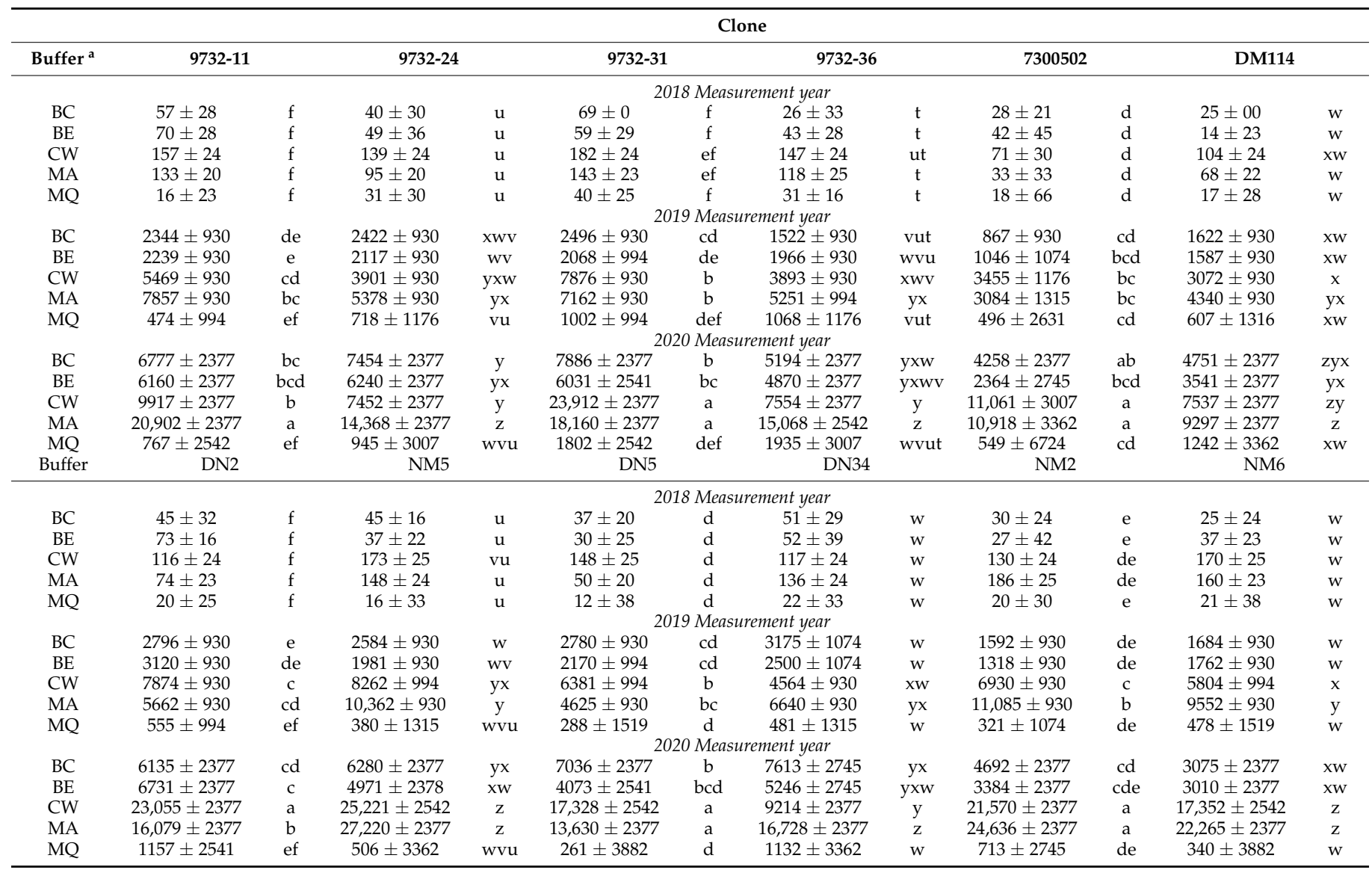

${ }^{a}$ BC: Bellevue (Central); BE: Bellevue (East); CW: Caledonia (West); MA: Manitowoc; MQ: Marquette.

As in previous buffer groups, 'DM114' was a high-level generalist. With the exception of ' 99038022 ' that was a high-level generalist with nearly universal rank stability, only two substantial rank changes across all three-way combinations, and moderate stability over time, the NRRI clones were specialists for the 2019 buffer group. In particular, '9732-11', '9732-24', '9732-31', and '9732-36' were moderate- to high-level specialists characterized by broad rank variability, substantial rank changes, and moderate stability over time. Similarly, the performance of 'DN2' as a generalist in the 2019 buffer group was different relative to its specialist volume in the 2018 buffer group. Across 2019 phyto buffers, 'DN2' exhibited moderate rank stability within years and consistent ranks over time. All remaining clones were moderate- ('DN34', 'DN177') and high-level ('NM2', 'NM5', 'NM6') specialists with trends for changes in magnitude and rank similar to their performance in 2017 and 2018 buffer groups (Table S12). 
Table 7. Volume $\left(\mathrm{cm}^{3}\right)$ ( \pm one standard error) of twelve poplar clones tested in five phytoremediation buffer systems (i.e., phyto buffers) established in 2019 (i.e., the 2019 buffer group) in the Lake Superior watershed of the Upper Peninsula of Michigan, USA. Trees were measured following the 2019 and 2020 growing seasons. Volume values with different letters within a clone column across measurement years are different at $P<0.05$.

\begin{tabular}{|c|c|c|c|c|c|c|c|c|c|c|c|c|}
\hline \multirow[b]{2}{*}{ Buffer ${ }^{a}$} & \multicolumn{12}{|c|}{ Clone } \\
\hline & \multicolumn{2}{|l|}{99038022} & \multicolumn{2}{|l|}{ 9732-11 } & \multicolumn{2}{|c|}{ 9732-24 } & \multicolumn{2}{|c|}{ 9732-31 } & \multicolumn{2}{|c|}{ 9732-36 } & \multicolumn{2}{|c|}{ DM114 } \\
\hline & \multicolumn{12}{|c|}{2019 Measurement year } \\
\hline $\mathrm{EE}$ & $73 \pm 26$ & $\mathrm{~b}$ & $49 \pm 25$ & $\mathrm{y}$ & $98 \pm 26$ & c & $81 \pm 28$ & $\mathrm{y}$ & $44 \pm 27$ & $\mathrm{~d}$ & $47 \pm 26$ & $\mathrm{y}$ \\
\hline EW & $396 \pm 27$ & b & $239 \pm 27$ & $\mathrm{y}$ & $198 \pm 27$ & c & $228 \pm 27$ & $\mathrm{y}$ & $312 \pm 27$ & $\mathrm{~cd}$ & $215 \pm 27$ & $\mathrm{y}$ \\
\hline MU & $89 \pm 26$ & $\mathrm{~b}$ & $28 \pm 26$ & $\mathrm{y}$ & $49 \pm 26$ & c & $20 \pm 27$ & $\mathrm{y}$ & $47 \pm 26$ & $\mathrm{~d}$ & $38 \pm 26$ & $\mathrm{y}$ \\
\hline ON & $54 \pm 27$ & $\mathrm{~b}$ & $28 \pm 27$ & $\mathrm{y}$ & $23 \pm 27$ & c & $29 \pm 27$ & $\mathrm{y}$ & $16 \pm 27$ & $\mathrm{~d}$ & $36 \pm 27$ & $\mathrm{y}$ \\
\hline \multirow{2}{*}{ OS } & $60 \pm 27$ & $\mathrm{~b}$ & $49 \pm 27$ & $\mathrm{y}$ & $56 \pm 27$ & c & $33 \pm 28$ & $\mathrm{y}$ & $28 \pm 27$ & $\mathrm{~d}$ & $42 \pm 27$ & $\mathrm{y}$ \\
\hline & \multicolumn{12}{|c|}{2020 Measurement year } \\
\hline $\mathrm{EE}$ & $517 \pm 573$ & $\mathrm{~b}$ & $470 \pm 573$ & $\mathrm{y}$ & $1553 \pm 573$ & $a b$ & $1040 \pm 613$ & zy & $463 \pm 573$ & bc & $828 \pm 573$ & $\mathrm{y}$ \\
\hline EW & $2397 \pm 573$ & $\mathrm{a}$ & $2206 \pm 573$ & $\mathrm{z}$ & $2444 \pm 573$ & $\mathrm{a}$ & $2155 \pm 573$ & $\mathrm{z}$ & $3189 \pm 573$ & $\mathrm{a}$ & $3166 \pm 573$ & $\mathrm{z}$ \\
\hline MU & $2075 \pm 573$ & $\mathrm{a}$ & $878 \pm 573$ & zy & $1709 \pm 573$ & $a b$ & $950 \pm 573$ & zy & $1761 \pm 573$ & a & $2463 \pm 573$ & $\mathrm{z}$ \\
\hline $\mathrm{ON}$ & $691 \pm 573$ & $\mathrm{~b}$ & $205 \pm 573$ & $\mathrm{y}$ & $189 \pm 573$ & c & $295 \pm 573$ & $\mathrm{y}$ & $285 \pm 573$ & $\mathrm{~cd}$ & $924 \pm 573$ & $\mathrm{y}$ \\
\hline OS & $439 \pm 573$ & $\mathrm{~b}$ & $785 \pm 573$ & zy & $805 \pm 573$ & bc & $494 \pm 613$ & $\mathrm{y}$ & $441 \pm 573$ & bcd & $806 \pm 573$ & $\mathrm{y}$ \\
\hline \multirow[t]{2}{*}{ Buffer } & \multicolumn{2}{|l|}{ DN2 } & DN177 & & \multicolumn{2}{|l|}{ NM5 } & \multicolumn{2}{|l|}{ DN34 } & \multicolumn{2}{|l|}{ NM2 } & \multicolumn{2}{|l|}{ NM6 } \\
\hline & \multicolumn{12}{|c|}{2019 Measurement year } \\
\hline $\mathrm{EE}$ & $45 \pm 26$ & $\mathrm{~b}$ & $56 \pm 26$ & $\mathrm{y}$ & $42 \pm 26$ & c & $50 \pm 26$ & $\mathrm{y}$ & $43 \pm 27$ & $\mathrm{~b}$ & $47 \pm 26$ & $\mathrm{x}$ \\
\hline EW & $382 \pm 27$ & $\mathrm{~b}$ & $231 \pm 27$ & $\mathrm{y}$ & $304 \pm 27$ & c & $278 \pm 27$ & $\mathrm{y}$ & $337 \pm 27$ & $\mathrm{~b}$ & $269 \pm 27$ & $\mathrm{x}$ \\
\hline MU & $29 \pm 27$ & $\mathrm{~b}$ & $20 \pm 26$ & $\mathrm{y}$ & $45 \pm 27$ & c & $56 \pm 27$ & $\mathrm{y}$ & $35 \pm 27$ & $\mathrm{~b}$ & $60 \pm 27$ & $\mathrm{x}$ \\
\hline $\mathrm{ON}$ & $14 \pm 27$ & $\mathrm{~b}$ & $09 \pm 27$ & $\mathrm{y}$ & $24 \pm 29$ & c & $18 \pm 27$ & $\mathrm{y}$ & $26 \pm 27$ & $\mathrm{~b}$ & $29 \pm 27$ & $\mathrm{x}$ \\
\hline \multirow[t]{2}{*}{ OS } & $33 \pm 27$ & $\mathrm{~b}$ & $18 \pm 27$ & $\mathrm{y}$ & $25 \pm 27$ & c & $26 \pm 27$ & $\mathrm{y}$ & $26 \pm 27$ & b & $38 \pm 27$ & $\mathrm{x}$ \\
\hline & \multicolumn{12}{|c|}{2020 Measurement year } \\
\hline $\mathrm{EE}$ & $531 \pm 573$ & $\mathrm{~b}$ & $755 \pm 573$ & $\mathrm{y}$ & $543 \pm 573$ & bc & $668 \pm 573$ & $\mathrm{y}$ & $645 \pm 573$ & $\mathrm{~b}$ & $510 \pm 573$ & $\mathrm{x}$ \\
\hline EW & $2675 \pm 573$ & $\mathrm{a}$ & $2448 \pm 573$ & $\mathrm{z}$ & $7687 \pm 573$ & a & $1881 \pm 573$ & $\mathrm{z}$ & $8910 \pm 573$ & a & $6129 \pm 573$ & $\mathrm{z}$ \\
\hline MU & $1834 \pm 573$ & $\mathrm{a}$ & $1230 \pm 573$ & $\mathrm{z}$ & $1932 \pm 573$ & $\mathrm{~b}$ & $2245 \pm 573$ & $\mathrm{z}$ & $1770 \pm 573$ & $\mathrm{~b}$ & $3302 \pm 573$ & $\mathrm{y}$ \\
\hline $\mathrm{ON}$ & $206 \pm 573$ & $\mathrm{~b}$ & $106 \pm 573$ & $\mathrm{y}$ & $93 \pm 613$ & c & $275 \pm 573$ & $\mathrm{y}$ & $337 \pm 573$ & $\mathrm{~b}$ & $278 \pm 573$ & $\mathrm{x}$ \\
\hline OS & $727 \pm 573$ & $\mathrm{~b}$ & $305 \pm 573$ & $\mathrm{y}$ & $267 \pm 573$ & c & $515 \pm 573$ & $\mathrm{y}$ & $339 \pm 573$ & $\mathrm{~b}$ & $662 \pm 573$ & $\mathrm{x}$ \\
\hline
\end{tabular}

a EE: Escanaba (East); EW: Escanaba (West); MU: Munising; ON: Ontonagon (North); OS: Ontonagon (South).

\section{Discussion and Conclusions}

\subsection{Genotype $\times$ Environment Interactions}

Understanding genotype by environment $(G \times E)$ interactions is a necessary step for identifying and selecting poplar clones used for phytoremediation and associated phytotechnologies [68]. Poplar phenotypes are a function of their genotype, environment, and genotypic response to specific site conditions [49]. Phyto-recurrent selection has been used to choose superior poplar genotypes in the Midwestern United States [32,68]. Using both generalist and specialist genotypes enhances ecosystem services provided by phytoremediation applications. Deploying generalists with low $\mathrm{G} \times \mathrm{E}$ interactions and robust productivity across the region may be beneficial for cost and operational efficiencies $[47,56]$, while specialists with high $G \times E$ interactions may maximize productivity, phytoremediation potential, and overall benefits of ecosystem services $[26,28,49]$. In the current study, sixteen phytoremediation buffer systems (i.e., multi-environmental trials $(\mathrm{MET})$ ) were established to evaluate trends in $\mathrm{G} \times \mathrm{E}$ interactions and identify generalist and specialist poplars in order to reduce runoff and clean groundwater (Figure 1).

In this study there were significant main (buffer, clone, and year) and interaction effects on tree health and growth parameters. In particular, interactions involving the buffer main effect were major factors governing clonal productivity. Buffer effects reflect tree responses to combined edaphic and local climatic conditions, and influence clonal performance traits such as: stem biomass production [69,70]; foliar fungal microbiomes [71]; leaf characteristics [72]; and diameter, height, and wood volume production [49,73]. In the current study, the broad spectrum of MET buffers with varying soil and climate conditions led to a wide range in clonal performance related to changes in both genotypic magnitude and ranks over time. More favorable climatic conditions (i.e., warmer, more precipitation; Table 1) and adequate soils for poplar cultivation (e.g., suitable texture, water-air properties, $\mathrm{pH}$; Table 2) likely led to greater volume of most clones at Menomonee Falls, Slinger, Manitowoc and Caledonia. On the other hand, lower performance of clones at Marquette and Ontonagon can be attributed to less favorable climatic and soil conditions such as lower precipitation, temperature, and soil pH (i.e., more acidity). Similar results were 
obtained by Hansen et al. [74] who showed that soil water availability played a key role in the productivity of woody biomass plantations. In the current study, sites with irrigation or shallow water tables exhibited the greatest wood volume, which was further corroborated through poplar biomass productivity modeling in the Midwestern United States [59,60]. Overall, $\mathrm{G} \times \mathrm{E}$ interactions resulted in mean annual increment (MAI) of four-year-old trees from the current 2017 buffer group ranging from 1.1 to $7.8 \mathrm{Mg} \mathrm{ha}^{-1} \mathrm{yr}^{-1}$ (mean = 3.2 $\mathrm{Mg} \mathrm{ha}^{-1} \mathrm{yr}^{-1}$ ), which agreed with results for similarly-aged (i.e., 3 to 5 years) poplars in the region, whose MAI ranged from $0.6 \mathrm{Mg} \mathrm{ha}^{-1} \mathrm{yr}^{-1}$ to $7.1 \mathrm{Mg} \mathrm{ha}^{-1} \mathrm{yr}^{-1}$ [49,75].

Multi-environmental trials are key tools for defining gains achieved through identifying genotype characteristics, their stability, and relevance of their interaction with varying environmental conditions (i.e., $\mathrm{G} \times \mathrm{E}$ interactions) [76]. Although $\mathrm{G} \times \mathrm{E}$ interactions can have a significant impact on the precision of breeding value estimates, often resulting in decreased genetic gain [53], matching superior species and clones to particular site and growing conditions has been critical in maximizing the productivity of SRWC plantations [70]. Tree age is an important factor shown to govern $\mathrm{G} \times \mathrm{E}$ interactions for poplars. Although Riemenschneider et al. [48] found significant $G \times E$ interactions first occurring at three years after planting, Semerci et al. [52] recorded significant $G \times E$ interactions for growth and phenology traits in one-year-old poplar clones grown on sites with different water availability in Turkey. Similarly, in the present study, all tested traits exhibited G $\times \mathrm{E}$ interactions after the first year in all three buffer groups (e.g., for one- to four-year-old trees). In contrast to the results presented here, greenhouse phyto-recurrent selection experiments with soils from the six phyto buffers of the 2017 buffer group [Bellevue (West), Caledonia (East), Menomonee Falls (East), Menomonee Falls (West), Slinger, and Whitelaw] showed a lack of $G \times E$ interactions for root-shoot ratio and growth performance index of many poplar clones tested at the current MET. Nevertheless, there were significant $G \times E$ interactions for tree health [58]. Such differences may be attributed to variability in environmental conditions between the greenhouse and field buffers and/or the length of the experiment (i.e., months versus years).

Regardless, such results have indicated that $G \times E$ interactions in poplar clones vary during the life cycle of the trees. Zalesny and Headlee [25] found significant G $\times$ E interactions for biomass and carbon production in both 10- and 20-year-old poplar plantations, despite negligible genotypic effects on both traits for 20-year-old trees. The presence/absence of $\mathrm{G} \times \mathrm{E}$ interactions within clones during the production cycle also can be expressed by variability in growth patterns across clones. Netzer et al. [77] recorded that some clones had greater biomass productivity in the second half of the stand rotation, while Ghezehei et al. [78] recorded both lack and presence of significant differences in clonal productivity of four- and eight-year-old poplars.

\subsection{Generalist and Specialist Response Groups}

Phenotypic responses determine comparative genotypic performance, resulting in some clones growing well and providing higher levels of ecosystem services across a broad range of soil, climate, and/or contaminant conditions (i.e., generalists). On the other hand, specialists optimize their growth and physiological processes when subjected to specific site conditions [43,44]. We identified both generalist ('DM114', 'NC14106', '99038022', '99059016') and specialist ('7300502', 'DN5', 'DN34', 'DN177', 'NM2', 'NM5', 'NM6') clones, along with others that exhibited volume consistent with both response groups across buffers and years ('9732-11', '9732-24', '9732-31', '9732-36', 'DN2') (i.e., those that shifted from generalists to specialists as trees aged; see below) (Table S13). Classification of these clones has important practical implications in reducing uncertainties associated with fielddeployment of these genotypes for multiple applications, including phytoremediation.

Changes in both magnitude and ranks across buffer $\times$ clone $\times$ year combinations defined the $\mathrm{G} \times \mathrm{E}$ interactions of the current study [43,44]. Different classifications were found for volume versus mean annual increment (MAI), which supports the need for longterm monitoring throughout plantation development [68]. One explanation for differences 
between these traits may be related to the age at which the trees were measured. As noted previously, in the Southeastern United States, clonal rankings in poplar wood volume production changed with increasing stand age $[70,79]$. In this study, all volume estimates were from one- to three-year-old trees, while MAI was determined for trees after their fourth growing season, the start of the mid-rotation growth stage for poplars used for phytoremediation [80]. Similar changes were also apparent when evaluating measurement years within individual buffer groups. That is, oftentimes clonal rankings dramatically changed as trees aged (e.g., '7300502' had the greatest volume at Slinger during the establishment year only to have the least volume at this buffer after two and three growing seasons). A second explanation for differences in classifications between volume and MAI may be related to individual clones expressing higher levels of genetic variation and phenotypic plasticity as they responded to highly variable and changing soil conditions both within and across growing seasons at the phyto buffers. Guet et al. [72] reported that $P$. deltoides and P. nigra (which were the most common species used as parents in the current study) exhibited high levels of such genetic variation and plasticity, allowing them to better adapt to site-level spatial and temporal heterogeneity. These responses could lead to a greater propensity for specialist growth performance, and may explain why some NRRI clones ('9732-11', '9732-24', '9732-31', '9732-36') shifted from generalists to specialists in the current study (Table S13). In contrast, Nelson et al. [46] identified most of these clones as being geographically robust across both latitudinal and longitudinal gradients in North America. One of these clones, '9732-36', had very consistent volume production in our 2017 and 2018 buffer groups (as well as MAI in our 2017 buffer group), yet trended towards specialist responses at phyto buffers established in 2019. This may have been due to a negligible relationship between phenotypic plasticity and $\mathrm{G} \times \mathrm{E}$ interactions. As in our interpretation (and its definition), Des Marais et al. [81] linked $G \times E$ interactions to changes in clonal ranking and growth performance (i.e., variance-changing interaction) [56].

This concept of variance-changing interaction also supports differences in classifying generalist and specialist clones of the current study within individual measurement years associated with buffer $\times$ clone interactions for specific buffer groups. Specifically, individual response group designations for buffer $\times$ clone $\times$ year combinations (from Tables S6, S9 and S12) may differ somewhat from final classifications listed in Table S13, given the need to assess stability and magnitude of ranks within years and over time (i.e., classifying the clones holistically). With the exception of the NRRI clones, most other genotypes from the P. deltoides $\times$ P. nigra 'DN' genomic group (with 'DN2' being the only exception), as well as the P. deltoides ' $\mathrm{D}$ ' clone '7300502' and all clones of the P. deltoides $\times$ P. maximowiczii ' $\mathrm{DM}$ ' and P. nigra $\times$ P. maximowiczii 'NM" genomic groups exhibited consistent classifications across buffer groups. Nevertheless, of particular interest was that individual clones within genomic groups (or breeding groups, for the ' $\mathrm{DN}$ ' hybrids) performed similarly, indicating that selection of genomic groups may be effective for early phyto-recurrent selection cycles (i.e., when choosing base populations for testing). Such genomic group trends have been reported for the same or related genotypes used in other phytoremediation applications $[35,82]$. Overall, the preponderance of specialist clones in the current study supports the need for phyto-recurrent selection in order to match genotypes to sites for small-scale applications with location-specific requirements (i.e., see variation in ranks for 'NM5' from Tables S6, S9 and S12), as well as the parallel need for continued testing of new genetic material, such as the NRRI clones, to select robust genotypes with minimal $\mathrm{G} \times \mathrm{E}$ interactions that can be used for large-scale, commercial applications at a justifiable cost while providing a multitude of ecosystem services across the rural to urban continuum [46].

Supplementary Materials: The following are available online at https:/ / www.mdpi.com/article/10 .3390/f12040430/s1; Table S1: Dates of planting for each phytoremediation buffer system (i.e., phyto buffer); Table S2: Probability values from analyses of variance for health and mean annual increment (MAI); Table S3: Probability values from analyses of variance for height, diameter, and volume; Table S4: Height for the buffer $\times$ clone $\times$ year interaction (2017 buffer group); Table S5: Diameter 
for the buffer $\times$ clone $\times$ year interaction (2017 buffer group); Table S6: Volume clone rank for the buffer $\times$ clone $\times$ year interaction $(2017$ buffer group); Table S7: Height for the buffer $\times$ clone $\times$ year interaction (2018 buffer group); Table S8: Diameter for the buffer $\times$ clone $\times$ year interaction $(2018$ buffer group); Table S9: Volume clone rank for the buffer $\times$ clone $\times$ year interaction (2018 buffer group); Table S10: Height for the buffer $\times$ clone $\times$ year interaction (2019 buffer group); Table S11: Diameter for the buffer $\times$ clone $\times$ year interaction (2019 buffer group); Table S12: Volume clone rank for the buffer $\times$ clone $\times$ year interaction (2019 buffer group); Table S13: Final classification of clones into generalist and specialist response groups; Figure S1: Health for the buffer $\times$ clone interaction measured in 2018 (2017 buffer group); Figure S2: Health for the buffer $\times$ clone interaction measured in 2019 (2017 buffer group); Figure S3: Health for the buffer $\times$ clone interaction measured in 2019 (2018 buffer group).

Author Contributions: Conceptualization, E.O.B., L.B., J.G.B., B.S.D., R.A.H., C.-H.L., M.P., R.S., A.H.W., and R.S.Z.J.; methodology, E.O.B., J.G.B., B.S.D., R.A.H., C.-H.L., B.G.M., A.P., E.R.R., R.S., R.A.V., A.H.W., and R.S.Z.J.; validation, A.P., E.R.R., and R.S.Z.J.; formal analysis, R.S.Z.J.; investigation, E.O.B., J.G.B., B.S.D., R.A.H., C.-H.L., B.G.M., N.D.N., A.P., E.R.R., R.A.V., A.H.W., and R.S.Z.J.; resources, L.B., J.G.B., R.A.H., C.-H.L., B.G.M., N.D.N., M.P., R.S., and R.S.Z.J.; data curation, B.S.D., E.R.R., R.A.V., A.H.W., and R.S.Z.J.; writing-original draft preparation, A.P., E.R.R., and R.S.Z.J.; writing-review and editing, E.O.B., L.B., J.G.B., B.S.D., R.A.H., C.-H.L., B.G.M., N.D.N., M.P., A.P., E.R.R., R.S., R.A.V., A.H.W., and R.S.Z.J.; visualization, E.R.R., and R.S.Z.J.; supervision, J.G.B., B.S.D., C.-H.L., N.D.N., E.R.R., A.H.W., and R.S.Z.J.; project administration, J.G.B., C.-H.L., and R.S.Z.J.; funding acquisition, A.H.W. and R.S.Z.J. All authors have read and agreed to the published version of the manuscript.

Funding: This work was funded by the Great Lakes Restoration Initiative (GLRI; Template \#738 Landfill Runoff Reduction).

Acknowledgments: The findings and conclusions in this publication are those of the authors and should not be construed to represent any official USDA or United States Government determination or policy. This work was funded by the Great Lakes Restoration Initiative (GLRI; Template \#738 Landfill Runoff Reduction). We are grateful to S. Johnson, C.H. Perry, and N. Vrevich of the USDA Forest Service for GLRI support. We thank B. Dean (formerly), K. Corcoran, and M. Mujaddedi of the International Programs Office of the USDA Forest Service for administrative support of scientific exchanges between A. Pilipović and R. Zalesny, as well as their administration and support of International Forestry Fellows: D. Karlsson (Sweden), P. Muñoz Gomez de la Serna (Spain), and A. Peqini (Albania). We thank the following site managers for access to their field sites: J. Forney and B. Pliska (Waste Management, Inc.); K. Dorow, D. Koski, and K. McDaniel (City of Manitowoc, Wisconsin); D. Henderson (AECOM Technical Services, Inc.); B. Austin and J. Wales (Marquette County Solid Waste Management Authority); D. Pyle (Delta County Solid Waste Management Authority); and S. Coron (Great American Disposal), as well as T. Beggs (Wisconsin Department of Natural Resources) for regulatory assistance and B. Sexton (Sand County Environmental) for insight, knowledge, and guidance on sustainable phytoremediation systems. We appreciate laboratory, greenhouse, and field technical assistance from: B.A. Birr, T. Cook, S. Eddy, F. Erdmann, C. Espinosa, D. Karlsson, R. Lange, P. Manley, M. Mueller, C. Munch, P. Muñoz Gomez de la Serna, D. Nguyen, A. Peqini, M. Ramsay, E. Schmidt, J. Schutts, and M. Wagler. We are grateful to J.M. Suvada for developing Figure 1, as well as R. Klevickas and P. Bloese for providing cutting material. We thank W.L. Headlee for statistical mentoring and reviewing earlier versions of this manuscript.

Conflicts of Interest: The authors declare no conflict of interest.

\section{References}

1. Fuller, K.; Shear, H.; Wittig, J. The Great Lakes: An Environmental Atlas and Resource Book, 3rd ed; U.S. Environmental Protection Agency and Government of Canada: Washington, DC, USA, 1995; Volume 95, p. 46, Issue 1 of EPA 905-B.

2. GLRI (Great Lakes Restoration Initiative). Action Plan I (2010-2014); GLRI: Washington, DC, USA, 2010; 41p.

3. MEA (Millenium Ecosystem Assessment). Ecosystems and Human Well-Being: Synthesis; Island Press: Washington, DC, USA, 2005; p. 155.

4. Steinman, A.D.; Cardinale, B.J.; Munns, W.R.; Ogdahl, M.E.; Allan, J.D.; Angadi, T.; Bartlett, S.; Brauman, K.; Byappanahalli, M.; Doss, M.; et al. Ecosystem services in the Great Lakes. J. Great Lakes Res. 2017, 43, 161-168. [CrossRef]

5. Michigan Sea Grant. Available online: https://www.michiganseagrant.org (accessed on 8 April 2020). 
6. Campbell, M.; Cooper, M.J.; Friedman, K.; Anderson, W.P. The economy as a driver of change in the Great Lakes-St. Lawrence River basin. J. Great Lakes Res. 2015, 41, 69-83. [CrossRef]

7. Allan, J.D.; McIntyre, P.B.; Smith, S.D.P.; Halpern, B.S.; Boyer, G.L.; Buchsbaum, A.; Burton, G.A.; Campbell, L.M.; Chadderton, W.L.; Ciborowski, J.J.H.; et al. Joint analysis of stressors and ecosystem services to enhance restoration effectiveness. Proc. Natl. Acad. Sci. USA 2012, 110, 372-377. [CrossRef] [PubMed]

8. Vörösmarty, C.J.; Sahagian, D. Anthropogenic disturbance of the terrestrial water cycle. BioScience 2000, 50, 753-765. [CrossRef]

9. Donohoe, M. Causes and health consequences of environmental degradation and social injustice. Soc. Sci. Med. 2003, 56, 573-587. [CrossRef]

10. Wu, Q.; Zhou, H.; Tam, N.F.; Tian, Y.; Tan, Y.; Zhou, S.; Li, Q.; Chen, Y.; Leung, J.Y. Contamination, toxicity and speciation of heavy metals in an industrialized urban river: Implications for the dispersal of heavy metals. Mar. Pollut. Bull. 2016, 104, 153-161. [CrossRef] [PubMed]

11. Cureton, P.M.; Groenevelt, P.H.; McBride, R.A. Landfill Leachate Recirculation: Effects on Vegetation Vigor and Clay Surface Cover Infiltration. J. Environ. Qual. 1991, 20, 17-24. [CrossRef]

12. Kjeldsen, P.; Barlaz, M.A.; Rooker, A.P.; Baun, A.; Ledin, A.; Christensen, T.H. Present and Long-Term Composition of MSW Landfill Leachate: A Review. Crit. Rev. Environ. Sci. Technol. 2002, 32, 297-336. [CrossRef]

13. Duggan, J. The potential for landfill leachate treatment using willows in the UK-A critical review. Resour. Conserv. Recycl. 2005, 45, 97-113. [CrossRef]

14. Wong, M.; Leung, C. Landfill Leachate as Irrigation Water for Tree and Vegetable Crops. Waste Manag. Res. 1989, 7, 311-323. [CrossRef]

15. Allan, J.D.; Smith, S.D.; McIntyre, P.B.; A Joseph, C.; E Dickinson, C.; Marino, A.L.; Biel, R.G.; Olson, J.C.; Doran, P.J.; Rutherford, E.S.; et al. Using cultural ecosystem services to inform restoration priorities in the Laurentian Great Lakes. Front. Ecol. Environ. 2015, 13, 418-424. [CrossRef]

16. Wortley, L.; Hero, J.-M.; Howes, M.J. Evaluating Ecological Restoration Success: A Review of the Literature. Restor. Ecol. 2013, 21, 537-543. [CrossRef]

17. Nunez-Mir, G.C.; Iannone, B.V.; Curtis, K.; Fei, S. Evaluating the evolution of forest restoration research in a changing world: A "big literature" review. New For. 2015, 46, 669-682. [CrossRef]

18. Lima, A.T.; Mitchell, K.; O'Connell, D.W.; Verhoeven, J.; Van Cappellen, P. The legacy of surface mining: Remediation, restoration, reclamation and rehabilitation. Environ. Sci. Policy 2016, 66, 227-233. [CrossRef]

19. Arthur, E.L.; Rice, P.J.; Rice, P.J.; Anderson, T.A.; Baladi, S.M.; Henderson, K.L.D.; Coats, J.R. Phytoremediation-An Overview. Crit. Rev. Plant Sci. 2005, 24, 109-122. [CrossRef]

20. Burken, J.G.; Schnoor, J.L. Predictive Relationships for Uptake of Organic Contaminants by Hybrid Poplar Trees. Environ. Sci. Technol. 1998, 32, 3379-3385. [CrossRef]

21. Cooke, J.A.; Johnson, M.S. Ecological restoration of land with particular reference to the mining of metals and industrial minerals: A review of theory and practice. Environ. Rev. 2002, 10, 41-71. [CrossRef]

22. Chaney, R.L.; Baklanov, I.A. Phytoremediation and Phytomining. Adv. Bot. Res. 2017, 83, 189-221. [CrossRef]

23. Dickmann, D. Silviculture and biology of short-rotation woody crops in temperate regions: Then and now. Biomass Bioenergy 2006, 30, 696-705. [CrossRef]

24. Johnson, J.M.; Coleman, M.D.; Gesch, R.W.; Jaradat, A.A.; Mitchell, R.; Reicosky, D.C.; Wilhelm, W.W. Biomass-bioenergy crops in the United States: A changing paradigm. Am. J. Plant Sci. Biotechnol. 2007, 1, 1-28.

25. Zalesny, R.S., Jr.; Headlee, W.L. Developing Woody Crops for the Enhancement of Ecosystem Services under Changing Climates in the North Central United States. J. For. Environ. Sci. 2015, 31, 78-90. [CrossRef]

26. Zalesny, R.S., Jr.; Stanturf, J.A.; Gardiner, E.S.; Perdue, J.H.; Young, T.M.; Coyle, D.R.; Headlee, W.L.; Bañuelos, G.S.; Hass, A. Ecosystem Services of Woody Crop Production Systems. BioEnergy Res. 2016, 9, 465-491. [CrossRef]

27. Zalesny, R.S., Jr.; Berndes, G.; Dimitriou, I.; Fritsche, U.; Miller, C.; Eisenbies, M.; Ghezehei, S.; Hazel, D.; Headlee, W.L.; MolaYudego, B.; et al. Positive water linkages of producing short rotation poplars and willows for bioenergy and phytotechnologies. Wiley Interdiscip. Rev. Energy Environ. 2019, 8, 345. [CrossRef]

28. Zalesny, R.S., Jr.; Stanturf, J.A.; Gardiner, E.S.; Bañuelos, G.S.; Hallett, R.A.; Hass, A.; Stange, C.M.; Perdue, J.H.; Young, T.M.; Coyle, D.R.; et al. Environmental Technologies of Woody Crop Production Systems. BioEnergy Res. 2016, 9, 492-506. [CrossRef]

29. Licht, L.A.; Isebrands, J. Linking phytoremediated pollutant removal to biomass economic opportunities. Biomass Bioenergy 2005, 28, 203-218. [CrossRef]

30. Pilipović, A.; Orlovic, S.; Rončević, S.; Nikolić, N.; Župunski, M.; Spasojevic, J. Results of selection of poplars and willows for water and sediment phytoremediation. J. Agric. For. 2015, 61, 205-211. [CrossRef]

31. Zalesny, R.S., Jr.; E Riemenschneider, D.; Hall, R.B. Early rooting of dormant hardwood cuttings of Populus: Analysis of quantitative genetics and genotype $\times$ environment interactions. Can. J. For. Res. 2005, 35, 918-929. [CrossRef]

32. Zalesny, J.A.; Zalesny, R.S., Jr.; Wiese, A.H.; Hall, R.B. Choosing Tree Genotypes for Phytoremediation of Landfill Leachate Using Phyto-Recurrent Selection. Int. J. Phytoremediat. 2007, 9, 513-530. [CrossRef]

33. Pilipović, A.; Orlović, S.; Nikolić, N.; Borišev, M.; Krstić, B.; Rončević, S. Growth and plant physiological parameters as markers for selection of poplar clones for crude oil phytoremediation. Šumarski List 2012, 136, 273-281. 
34. Nikolić, N.; Zorić, L.; Cvetković, I.; Pajević, S.; Borišev, M.; Orlović, S.; Pilipović, A. Assessment of cadmium tolerance and phytoextraction ability in young Populus deltoides L. and Populus $\times$ euramericana plants through morpho-anatomical and physiological responses to growth in cadmium enriched soil. iForest Biogeosci. For. 2017, 10, 635-644. [CrossRef]

35. Zalesny, R.S., Jr.; Bauer, E.O. Genotypic variability and stability of poplars and willows grown onnitrate-contaminated soils. Int. J. Phytoremediat. 2019, 21, 969-979. [CrossRef]

36. Orlović, S.; Guzina, V.; Merkulov, L. Genetic variability in anatomical, physiological and growth characteristics of hybrid poplar (Populus $\times$ euramericana Dode (Guinier)) and eastern cottonwood (Populus deltoides Bartr.) clones. Silvae Genet. 1998, 47, 183-189.

37. Reboud, X.; Bell, G. Experimental evolution in Chlamydomonas. III. Evolution of specialist and generalist types in environments that vary in space and time. Heredity 1997, 78, 507-514. [CrossRef]

38. Kassen, R. The experimental evolution of specialists, generalists, and the maintenance of diversity. J. Evol. Biol. 2002, 15, 173-190. [CrossRef]

39. Stout, A.B.; Schreiner, E.J. Results of a Project in Hybridizing Poplars. J. Hered. 1933, 24, 217-229. [CrossRef]

40. Bradshaw, H.; Ceulemans, R.; Davis, J.; Stettler, R. Emerging Model Systems in Plant Biology: Poplar (Populus) as A Model Forest Tree. J. Plant Growth Regul. 2000, 19, 306-313. [CrossRef]

41. Isebrands, J.; Zalesny, R.S., Jr. Reflections on the contributions of Populus research at Rhinelander, Wisconsin, USA. Can. J. For. Res. 2021, 51, 139-153. [CrossRef]

42. Sommer, R.J. Phenotypic Plasticity: From Theory and Genetics to Current and Future Challenges. Genetics 2020, 215, 1-13. [CrossRef]

43. De Leon, N.; Jannink, J.-L.; Edwards, J.W.; Kaeppler, S.M. Introduction to a Special Issue on Genotype by Environment Interaction. Crop. Sci. 2016, 56, 2081-2089. [CrossRef]

44. Li, Y.; Suontama, M.; Burdon, R.D.; Dungey, H.S. Genotype by environment interactions in forest tree breeding: Review of methodology and perspectives on research and application. Tree Genet. Genomes 2017, 13, 60. [CrossRef]

45. Calleja-Rodriguez, A.; Gull, B.A.; Wu, H.X.; Mullin, T.J.; Persson, T. Genotype-by-environment interactions and the dynamic relationship between tree vitality and height in northern Pinus sylvestris. Tree Genet. Genomes 2019, 15, 36. [CrossRef]

46. Nelson, N.D.; Berguson, W.E.; McMahon, B.G.; Meilan, R.; Smart, L.B.; Gouker, F.E.; Bloese, P.; Miller, R.; Volk, T.A.; Cai, M.; et al. Discovery of Geographically Robust Hybrid Poplar Clones. Silvae Genet. 2019, 68, 101-110. [CrossRef]

47. Nelson, N.D.; Meilan, R.; Berguson, W.E.; McMahon, B.G.; Cai, M.; Buchman, D. Growth performance of hybrid poplar clones on two agricultural sites with and without early irrigation and fertilization. Silvae Genet. 2019, 68, 58-66. [CrossRef]

48. Riemenschneider, D.E.; Isebrands, J.G.; Berguson, W.E.; Dickmann, D.I.; Hall, R.B.; Mohn, C.A.; Stanosz, G.R.; Tuskan, G.A. Poplar breeding and testing strategies in the north-central U.S.: Demonstration of potential yield and consideration of future research needs. For. Chron. 2001, 77, 245-253. [CrossRef]

49. Zalesny, R.S., Jr.; Hall, R.B.; Zalesny, J.A.; McMahon, B.G.; Berguson, W.E.; Stanosz, G.R. Biomass and Genotype $\times$ Environment Interactions of Populus Energy Crops in the Midwestern United States. BioEnergy Res. 2009, 2, 106-122. [CrossRef]

50. Sixto, H.; Salvia, J.; Barrio, M.; Ciria, M.P.; Cañellas, I. Genetic variation and genotype-environment interactions in short rotation Populus plantations in southern Europe. New For. 2011, 42, 163-177. [CrossRef]

51. Zalesny, R.S., Jr.; Bauer, E.O.; Hall, R.B.; Zalesny, J.A.; Kunzman, J.; Rog, C.J.; Riemenschneider, D.E. Clonal Variation in Survival and Growth of Hybrid Poplar and Willow in an in situ trial on Soils Heavily Contaminated with Petroleum Hydrocarbons. Int. J. Phytoremediat. 2005, 7, 177-197. [CrossRef]

52. Semerci, A.; Guevara, C.A.; Gonzalez-Benecke, C.A. Water availability effects on growth and phenology of 11 poplar cultivars growing in semiarid areas in Turkey. New For. 2020, 1-20. [CrossRef]

53. Pliura, A.; Zhang, S.; MacKay, J.; Bousquet, J. Genotypic variation in wood density and growth traits of poplar hybrids at four clonal trials. For. Ecol. Manag. 2007, 238, 92-106. [CrossRef]

54. Headlee, W.L.; Zalesny, R.S., Jr.; Hall, R.B.; Bauer, E.O.; Bender, B.; Birr, B.A.; Miller, R.O.; Randall, J.A.; Wiese, A.H.; Zalesny, R.S. Specific Gravity of Hybrid Poplars in the North-Central Region, USA: Within-Tree Variability and Site $\times$ Genotype Effects. Forests 2013, 4, 251-269. [CrossRef]

55. Cervera, M.T.; Storme, V.; Soto, A.; Ivens, B.; Van Montagu, M.; Rajora, O.P.; Boerjan, W. Intraspecific and interspecific genetic and phylogenetic relationships in the genus Populus based on AFLP markers. Theor. Appl. Genet. 2005, 111, 1440-1456. [CrossRef]

56. Nelson, N.D.; Berguson, W.E.; McMahon, B.G.; Cai, M.; Buchman, D.J. Growth performance and stability of hybrid poplar clones in simultaneous tests on six sites. Biomass Bioenergy 2018, 118, 115-125. [CrossRef]

57. Zalesny, R.S., Jr.; Bauer, E.O. Selecting and Utilizing Populus and Salixfor Landfill Covers: Implications for Leachate Irrigation. Int. J. Phytoremediat. 2007, 9, 497-511. [CrossRef]

58. Rogers, E.R.; Zalesny, R.S., Jr.; Hallett, R.A.; Headlee, W.L.; Wiese, A.H. Relationships among Root-Shoot Ratio, Early Growth, and Health of Hybrid Poplar and Willow Clones Grown in Different Landfill Soils. Forests 2019, 10, 49. [CrossRef]

59. Zalesny, R.S., Jr.; Donner, D.M.; Coyle, D.R.; Headlee, W.L. An approach for siting poplar energy production systems to increase productivity and associated ecosystem services. For. Ecol. Manag. 2012, 284, 45-58. [CrossRef]

60. Headlee, W.L.; Zalesny, R.S., Jr.; Donner, D.M.; Hall, R.B. Using a Process-Based Model (3-PG) to Predict and Map Hybrid Poplar Biomass Productivity in Minnesota and Wisconsin, USA. BioEnergy Res. 2012, 6, 196-210. [CrossRef]

61. Miller, R.O. Growth Variation Among Hybrid Poplar Varieties in Michigan, USA and the Implications for Commercial Biomass Production. BioEnergy Res. 2018, 11, 816-825. [CrossRef] 
62. Zalesny, R.S., Jr.; Burken, J.G.; Hallett, R.A.; Pilipović, A.; Wiese, A.H.; Rogers, E.R.; Bauer, E.O.; Buechel, L.; DeBauche, B.S.; Henderson, D.; et al. The Great Lakes Restoration Initiative: Reducing Runoff from landfills in the Great Lakes Basin, USA. In Proceedings of the 12th Biennial Short Rotation Woody Crops Operations Working Group Conference: 2018 Woody Crops International Conference, Rhinelander, WI, USA, 22-27 July 2018.

63. Zalesny, R.S., Jr.; Burken, J.G.; Hallett, R.A.; Wiese, A.H. Using Phyto-Recurrent Selection to Reduce Impacts of Runoff from Closed Landfills in the Lake Michigan Drainage Basin, USA. In Proceedings of the 14th International Phytotechnologies Conference: Phytotechnologies-New Sustainable Solutions for Environmental Challenges, Montreal, QC, Canada, 25-29 September 2017.

64. Hansen, E.A. Root length in young hybrid Populus plantations: Its implications for border width of research plots. For. Sci. 1981, 27, 808-814. [CrossRef]

65. Zavitkovski, J. Small plots with unplanted plot border can distort data in biomass production studies. Can. J. For. Res. 1981, 11, 9-12. [CrossRef]

66. Kershaw, J.A.; Ducey, M.J.; Beers, T.W.; Husch, B. Forest Mensuration; Wiley: Hoboken, NY, USA, 2016 ; p. 630.

67. Headlee, W.L.; Zalesny, R.S., Jr. Allometric Relationships for Aboveground Woody Biomass Differ Among Hybrid Poplar Genomic Groups and Clones in the North-Central USA. BioEnergy Res. 2019, 12, 966-976. [CrossRef]

68. Zalesny, R.S., Jr.; Headlee, W.L.; Gopalakrishnan, G.; Bauer, E.O.; Hall, R.B.; Hazel, D.W.; Isebrands, J.G.; Licht, L.A.; Negri, M.C.; Nichols, E.G.; et al. Ecosystem services of poplar at long-term phytoremediation sites in the Midwest and Southeast, United States. Wiley Interdiscip. Rev. Energy Environ. 2019, 8, 349. [CrossRef]

69. Fortier, J.; Gagnon, D.; Truax, B.; Lambert, F. Biomass and volume yield after 6 years in multiclonal hybrid poplar riparian buffer strips. Biomass Bioenergy 2010, 34, 1028-1040. [CrossRef]

70. Ghezehei, S.B.; Nichols, E.G.; Maier, C.A.; Hazel, D.W. Adaptability of Populus to Physiography and Growing Conditions in the Southeastern USA. Forests 2019, 10, 118. [CrossRef]

71. Bálint, M.; Bartha, L.; O’Hara, R.B.; Olson, M.S.; Otte, J.; Pfenninger, M.; Robertson, A.L.; Tiffin, P.; Schmitt, I. Relocation, high-latitude warming and host genetic identity shape the foliar fungal microbiome of poplars. Mol. Ecol. 2014, 24, 235-248. [CrossRef] [PubMed]

72. Guet, J.; Fabbrini, F.; Fichot, R.; Sabatti, M.; Bastien, C.; Brignolas, F. Genetic variation for leaf morphology, leaf structure and leaf carbon isotope discrimination in European populations of black poplar (Populus nigra L.). Tree Physiol. 2015, 35, 850-863. [CrossRef] [PubMed]

73. Dhillon, G.P.S.; Singh, A.; Singh, P.; Sidhu, D.S. Field Evaluation of Populus deltoides Bartr. ex Marsh. at Two Sites in Indo-gangetic Plains of India. Silvae Genet. 2010, 59, 1-7. [CrossRef]

74. Hansen, E.A.; Ostry, M.E.; Johnson, W.D.; Tolsted, D.N.; Netzer, D.A.; Berguson, W.E.; Hall, R.B. Field Performance of Populus in Short-Rotation Intensive Culture Plantations in the North-Central U.S.; USDA Forest Service: Washington, DC, USA, 1994; Volume 320, p. 13.

75. Hansen, E. Mid-rotation yields of biomass plantations in the north central U.S. Mid Rotat. Yields Biomass Plant. North Cent. U.S. 1992, 309, 8. [CrossRef]

76. Sixto, H.; Gil, P.; Ciria, P.; Camps, F.; Sánchez, M.; Cañellas, I.; Voltas, J. Performance of hybrid poplar clones in short rotation coppice in Mediterranean environments: Analysis of genotypic stability. GCB Bioenergy 2013, 6, 661-671. [CrossRef]

77. Netzer, D.; Tolsted, D.; Ostry, M.E.; Isebrands, J.G.; Riemenschneider, D.; Ward, K. Growth, Yield, and Disease Resistance of 7- to 12-Year-Old Poplar Clones in the North Central United States; USDA Forest Service: Washington, DC, USA, 2002; Volume 229 , p. 31.

78. Ghezehei, S.B.; Wright, J.; Zalesny, R.S., Jr.; Nichols, E.G.; Hazel, D.W. Matching site-suitable poplars to rotation length for optimized productivity. For. Ecol. Manag. 2020, 457, 117670. [CrossRef]

79. Ghezehei, S.B.; Nichols, E.G.; Hazel, D.W. Early Clonal Survival and Growth of Poplars Grown on North Carolina Piedmont and Mountain Marginal Lands. BioEnergy Res. 2016, 9, 548-558. [CrossRef]

80. Zalesny, R.S., Jr.; Zhu, J.Y.; Headlee, W.L.; Gleisner, R.; Pilipović, A.; Van Acker, J.; Bauer, E.O.; Birr, B.A.; Wiese, A.H. Ecosystem Services, Physiology, and Biofuels Recalcitrance of Poplars Grown for Landfill Phytoremediation. Plants 2020, 9, 1357. [CrossRef]

81. Marais, D.L.D.; Hernandez, K.M.; Juenger, T.E. Genotype-by-Environment Interaction and Plasticity: Exploring Genomic Responses of Plants to the Abiotic Environment. Annu. Rev. Ecol. Evol. Syst. 2013, 44, 5-29. [CrossRef]

82. Zalesny, J.A.; Zalesny, R.S.; Coyle, D.R.; Hall, R.B. Growth and biomass of Populus irrigated with landfill leachate. For. Ecol. Manag. 2007, 248, 143-152. [CrossRef] 